\title{
The fish fauna of Brokopondo Reservoir, Suriname, during 40 years of impoundment
}

\author{
Jan H. Mol*, Bernard de Mérona**, Paul E. Ouboter*** and Shamita Sahdew***
}

We investigated long-term changes in the fish fauna of Brokopondo Reservoir, Suriname, the first large reservoir $\left(1560 \mathrm{~km}^{2}\right)$ that was created in tropical rainforest. Before closure of the dam in 1964, the fish fauna of Suriname River had 172 species, high diversity and high evenness. The riverine fauna was dominated by small-sized species, but no single species was dominant in numbers. Large catfishes were dominant in biomass. Species were evenly distributed over riverine habitats: rapids, tributaries and main channel. Four years after closure of the dam, only 62 fish species were collected from Brokopondo Reservoir, but the composition of the fish fauna was still changing. The reservoir fauna in 1978 was very similar to the reservoir fauna in 2005, indicating that a stable equilibrium had been reached 14 years after closure of the dam. The reservoir fauna had 41 species, low diversity and low evenness. Most species of Suriname River and its tributaries with strict habitat requirements did not survive in Brokopondo Reservoir. Fish community structure was different among four habitats of Brokopondo Reservoir. The openwater habitat (10 species) was dominated by the piscivores Serrasalmus rhombeus, Acestrorhynchus microlepis and Cichla ocellaris and their prey Bryconops melanurus and two Hemiodus species. B. melanurus fed on zooplankton, Culicinae pupae and terrestrial invertebrates. Hemiodus fed on fine flocculent detritus, demonstrating that the detritus-based food chain was still important in late stages of reservoir development. Serrasalmus rhombeus also fed on peccaries that drowned when swimming across the large reservoir in rough weather. The shore community ( 27 species) was dominated by seven cichlids, but early stages and juveniles of the open-water species $S$. rhombeus and B. melanurus also occurred in the shore habitat. Fish biomass in the shore habitat was $66.5 \pm 59.9 \mathrm{~kg} \mathrm{ha}^{-1}$. The cichlid Geophagus surinamensis and the characid B. melanurus had a lower biomass in Brokopondo Reservoir than in Suriname River. Serrasalmus rhombeus showed reduced body length in Brokopondo Reservoir as compared to riverine populations.

Foram pesquisadas as modificações a longo prazo na ictiofauna do reservatório de Brokopondo, o primeiro de grande porte $\left(1560 \mathrm{~km}^{2}\right)$ construído em floresta tropical úmida. Antes do fechamento da barragem em 1964, a ictiofauna do rio Suriname possuía 172 espécies, com diversidade e equitabilidade altas. A fauna do rio era dominada por espécies de pequeno porte, mas nenhuma delas dominava em número de indivíduos. Em termos de biomassa, os grandes bagres eram dominantes. As espécies estavam homogeneamente distribuídas nos diferentes hábitats: corredeiras, afluentes e canal principal. Quatro anos depois do fechamento da barragem, somente 62 espécies de peixes foram coletadas no reservatório de Brokopondo, mas a composição da ictiofauna ainda estava mudando. Em 1978, a ictiofauna do reservatório era semelhante à de 2005, indicando que um equilíbrio estável foi atingindo 14 anos depois do fechamento da barragem. A ictiofauna do reservatório tinha 41 espécies, diversidade e equitabilitade baixas. A maioria das espécies do rio Suriname que tinham exigências estreitas de hábitat não sobreviveram no reservatório. A estrutura das comunidades de peixes foi diferente nos quatro hábitats do reservatório de Brokopondo. $\mathrm{O}$ hábitat das águas abertas (10 espécies) foi dominado pelos piscívoros Serrasalmus rhombeus, Acestrorhynchus microlepis e Cichla ocellaris e suas presas Bryconops melanurus e duas espécies de Hemiodus. Bryconops alimentou se de zooplâncton, pupas de Culicidae e invertebrados terrestres. Hemiodus alimentou se de detritos floculentos, demostrando que a cadeia alimentar baseada em detritos ainda era importante em estágios avançados de desenvolvimento dos reservatórios. Serrasalmus rhombeus também come queixadas que se afogam quando tentam atravessar nadando o grande reservatório em condições de mau tempo. A comunidade das margens ( 27 espécies) foi dominada por sete Cichlidae, embora estágios iniciais e juvenis das espécies de águas abertas (i.e. S. rhombeus e B. melanurus) também estivessem presentes nos hábitats da margem. A biomassa de peixes nos hábitats da margem foi de $66.5 \pm 59.9 \mathrm{~kg} \mathrm{ha}^{-1}$. O Cichlidae Geophagus surinamensis e o Characidae B. melanurus tiveram peso úmido menor no reservatório de Brokopondo do que no rio Suriname. Serrasalmus rhombeus apresentou comprimento menor no reservatório quando comparado com as populações do rio.

Key words: Dam, Man-made lake, Neotropical, River, Fish community.

\footnotetext{
*University of Suriname, Center for Agricultural Research in Suriname CELOS / Department of Biology, P.O.B. 9212, Paramaribo, Suriname.fisheco@celos.sr.org

**Institut de Recherche pour le Développement IRD, Laboratoire d'Écologie des Hydrosystèmes Fluviaux, Université Lyon 1, 43 Bd 11

Nov 1918,69622 Villeurbanne, France. bernard.de-merona@univ-lyon1.fr

***University of Suriname, National Zoological Collection Suriname, P.O.B.9212, Paramaribo, Suriname.nzcs@uvs.edu
} 


\section{Introduction}

Fishes of rivers and smaller streams are generally well adapted to deal with natural physical and chemical variations in space and time (Matthews, 1998), but when faced with human-induced alteration of their habitat most fishes die or escape from the disturbed stream. Habitat alteration is recognized as the single biggest cause of loss of freshwater fish diversity (Moyle \& Leidy, 1992). The construction of a dam in a large river results in a profound and large-scale transformation of its ecosystem. Upstream of the dam, the lotic, cyclic and variable riverine environment changes into a reservoir with standing water, reduced water-level variability and reduced physical structure. Because freshwater fish represent a basic food resource for human populations in the tropics, fish communities and fisheries in tropical reservoirs have been intensively studied (e.g. Densen \& Morris, 1999). Moreover, the high diversity of fish in tropical rivers allows in-deep ecological interpretations of the effects of damming on the functioning of fish communities (Mérona \& Vigouroux, 2005). Reservoirs with their lake-like environmental conditions do not provide habitats for most riverine fishes and, following the construction of a dam, diverse tropical riverine fish communities were gradually replaced by simpler reservoir communities with reduced species richness and diversity (LoweMcConnell, 1973; Vieira, 1982; Leite, 1993; Santos, 1995). Although studies of short-term changes in Neotropical fish faunas exist (e.g. Vieira, 1982; Leite, 1993; Santos, 1995; Ponton et al., 2000; Mérona et al., 2001, 2003; Mérona, 2002), few studies have addressed long-term impacts of dams on Neotropical fish communities (Agostinho et al., 1999).

Brokopondo Reservoir $\left(1560 \mathrm{~km}^{2}\right)$ in the Suriname River, Suriname, is one of the oldest (dam closed 1 February 1964) large hydroelectric reservoirs $\left(>1000 \mathrm{~km}^{2}\right)$ in the tropics and the first large one in tropical rainforest (Goodland, 1979). Suriname River is a medium-sized (length $500 \mathrm{~km}$, catchment $16,500 \mathrm{~km}^{2}$, discharge $440 \mathrm{~m}^{3} \mathrm{~s}^{-1}$ at outlet), clear-water (terminology of Sioli, 1950) river draining the weathered soils of the Precambrian Guayana Shield. Amazonian reservoirs pose particular problems related to intensive decomposition of inundated tropical rainforest vegetation (Tundisi et al., 1993). Severe deterioration of water quality in the reservoir and downstream of the dam resulting in local (reservoir) to extensive (downstream) fish kills, explosive increase of free floating macrophytes, large-scale production of 'greenhouse' gases, and vertical stratification with an anoxic hypolimnion were first described for Brokopondo Reservoir (Donselaar, 1968; Heide, 1982; Panday-Verheuvel, 1983).

The Brokopondo Dam clearly had negative effects on the diverse Suriname River fish fauna (Boeseman, 1964; Mees, 1967; Nijssen, 1967, 1969), but impact assessment was hampered by poor taxonomic knowledge of Surinamese freshwater fishes at the time of dam construction. The large 19631964 collection of Suriname River fishes in the Brokopondo Reservoir Area by M. Boeseman was not studied in its entirety. Ouboter \& Mol (1993) listed 86 fish species for the middle and upper Suriname River, but they did not examine the Boeseman collection. In 1967, Nijssen (1967, 1969; also see Richter \& Nijssen, 1980) collected only 62 fish species in Brokopondo Reservoir and in 1978 the number of reservoir fishes further declined to 37 species (Kapetsky, 1978; Richter $\&$ Nijssen, 1980). No surveys of Brokopondo Reservoir fishes have been carried out in the period 1978-2000 and it is not clear to what extent the reservoir fish communities had stabilized in 1978.

Agostinho et al. (1999) anticipated the following long term effects of reservoir aging on the fish fauna: a reduction in number of top-predators, mean size of species (and even within a species) and species richness, dominance of pelagic species and short-lived species with fast growth, and, in advanced stages of aging, dominance of species adapted to shallow water with low oxygen (first noticeable in littoral areas). Our objectives are to describe the pre-impoundment Suriname River fish fauna in the area of the future Brokopondo Reservoir (based on the 1963-1964 collection of Boeseman) and the fish fauna of Brokopondo Reservoir in 1967, 1978 and 2002-2005 in order to document impacts of the dam on the Suriname River fish fauna and long term changes in reservoir communities as hypothesized by Agostinho et al. (1999).

\section{Material and Methods}

\section{Study site.}

Suriname is situated between 2 and $6^{\circ} \mathrm{N}$ on the northeast Atlantic coast of South America and has a humid tropical climate (Af according to the system of Köppen; Köppen, 1936). Rainfall averages $2270 \mathrm{~mm} /$ year in the Brokopondo Reservoir area. Brokopondo Reservoir (officially known as 'Prof. Dr. Ir. W.J. Van Blommesteinmeer') is situated at $4^{\circ} 45^{\prime} \mathrm{N}, 55^{\circ} 05^{\prime} \mathrm{W}$ in terra firme (high dry-land, i.e. not flooded in wet season) rainforest of the Precambrian Guayana Shield in the Suriname River Basin.

The Suriname River has a length of approximately $500 \mathrm{~km}$, a catchment of $16,500 \mathrm{~km}^{2}$, and a discharge of $440 \mathrm{~m}^{3} \mathrm{~s}^{-1}$ at the outlet and 324 (214-756) $\mathrm{m}^{3} \mathrm{~s}^{-1}$ at Afobaka (Amatali, 1993). Prior to closure of the dam, the Suriname River in the area of the future Brokopondo Reservoir was a low gradient $(0.64 \mathrm{~m}$ per $\mathrm{km}$ ) river with alternation of wide, shallow reaches with rapids and large river islands, and narrow, slowly flowing, deeper runs about $300 \mathrm{~m}$ in width and 5-7 $\mathrm{m}$ deep (Hydraulic Research Division, 1970; Heide, 1982). The rapids (up to $5 \mathrm{~m}$ high) probably presented no biogeographic barrier to dispersal of fishes as most species would have been able to bypass the rapids during the rainy season when water levels rise up to $5 \mathrm{~m}$ (Table 1). Drainage density was high and the river probably had narrow floodplains (approximately 10-200 $\mathrm{m}$ in width) without permanent lakes (similar to the middle Coppename River; Clarke \& Rhodes, 2006). With $84.8 \%$ of its catchment in the weathered soils of the Guayana Shield, the Suriname River had many characteristics of a clear-water river (terminology of Sioli, 1950), i.e. low annual sediment transport (7000 $\mathrm{m}^{3} /$ year at Brokopondo; Ringma, 1953), high Secchidisc transparency (1-2 $\mathrm{m})$, oligotrophic water $\left(\mathrm{NO}_{3}, \mathrm{NO}_{2}, \mathrm{PO}_{4}\right.$ and $\left.\mathrm{SO}_{4}<0.1 \mathrm{mg} / \mathrm{L}\right)$ with low conductivity $(15-23 \mu \mathrm{S} / \mathrm{cm})$, and pH 5.3-6.3 (Table 1). The water was saturated with dissolved 
oxygen from surface to bottom, and water temperature varied between 27 and $31^{\circ} \mathrm{C}$ (Table 1). Plankton was dominated by desmids and diatoms; zooplankton was sparse (Heide, 1982). Podostemaceae were abundant in rapids, and free floating macrophytes only occurred in small groups widely scattered along the banks (Donselaar, 1989). Shaded tributaries had higher conductivity, lower oxygen concentration, lower temperature, and less plankton than Suriname River.

The $54 \mathrm{~m}$ high dam at Afobaka, 194 river $\mathrm{km}$ from the estuary (Fig. 1), was constructed without fish ladders or other artificial devices to lessen the impact of the dam on fish migrations. The following description is based mainly on Heide (1982). The orientation of Brokopondo Reservoir is approximately north-south: the shortest distance from Afobaka Dam to Pokigron is $56 \mathrm{~km}$ and reservoir width averages $32 \mathrm{~km}$ (Fig. 1). The reservoir area at maximum normal water level is $1560 \mathrm{~km}^{2}$; some 1160 hill tops $\left(197 \mathrm{~km}^{2}\right)$ formed islands. Reservoir periphery shoreline is estimated at $1770 \mathrm{~km}$, but total shoreline, including islands, is approximately $3700 \mathrm{~km}$. The catchment of the reservoir is $12,550 \mathrm{~km}^{2}$ (i.e. $76 \%$ of the Suriname River Ba$\sin )$. The reservoir was considered to be filled when the minimum water level for operation of the $180 \mathrm{MW}$ power station, 41.2 m NSP ('Normaal Surinaams Peil' or New Surinamese Level), was reached in 1968. The water level had risen to the level of overflow in 1971. In 1971-1977, the average water level at Afobaka Dam (maximum depth of the reservoir) was $46.9 \mathrm{~m} \mathrm{NSP}$ and corresponding mean depth $11.5 \mathrm{~m}$. Within-year water level fluctuation varied between 1.4 and $5.3 \mathrm{~m}$ (Kapetsky, 1978). The volume of the reservoir is $22.7 \mathrm{~km}^{3}$ at maximum water level of $48.2 \mathrm{~m} \mathrm{NSP}$ and, given a yearly discharge of $9.7 \mathrm{~km}^{3}$ year $^{-1}$, residence time of the water is approximately 28 months. The long residence time reflects the small reservoir catchment and low relief in the reservoir area with average slope of the lake bottom $1.1 \%$.

Chemical and biological developments in the forming reservoir were determined largely by (1) the change from turbulence and mixing under riverine conditions to stagnation and stratification in lacustrine conditions and (2) the decomposition of the drowned rainforest vegetation. Extreme consumption of dissolved oxygen by decaying forest litter and vegetation caused fish mortality, both in the reservoir and in the Suriname River downstream of the dam (Boeseman, 1964; Mees, 1967). In the period 1964-1967, a thermal stratification gradually developed in the reservoir following the death of trees (and loss of their leaves). In surface water (epilimnion), temperature, dissolved oxygen and transparency increased (Table 1) and a eutrophic plankton type with euglenas and zooplankton developed. Deep water (hypolimnion) remained anoxic with relatively low temperature, high electrolytes (conductivity) and gases $\mathrm{H}_{2} \mathrm{~S}$ and $\mathrm{CH}_{4}$. The mineralization of organic matter of the inundated forest resulted in abundant growth of floating macrophytes, ultimately covering $582 \mathrm{~km}^{2}$ (or 75\% of the lake area) in 1966 (Donselaar, 1968). Aerial spraying with herbicide had eradicated most floating aquatic macrophytes by 1970, but decomposition of these water plants resulted in low dissolved oxygen levels in the hypolimnion in 1970-1976 (Panday-Verheuvel, 1983). The period 1980-2005 showed improvement in water quality and return to oligotrophy with $>3 \mathrm{mg} / \mathrm{L} \mathrm{O}_{2}$ at the bottom of the lake (except at extreme depths), high dissolved oxygen $>5.5 \mathrm{mg} / \mathrm{L}$ in surface water (0-5 m), conductivity 20-30 $\mu \mathrm{S} / \mathrm{cm}, \mathrm{pH} 5.5-7.0$, and transparency of $3 \mathrm{~m}$ (Table 1). Shore vegetation of submerged or emergent macrophytes was poorly developed. Because

Table 1. Water quality of Suriname River and forest streams in future Brokopondo Reservoir area before closing of the dam in 1964 and Brokopondo Reservoir in the period 1964-present. Data are presented as minimum and maximum values, except for dissolved oxygen concentrations in Brokopondo Reservoir (means). Data sources are Van der Heide (1982) ${ }^{1}$, Hydraulic Research Division (1970; years 1952-1964) ${ }^{2}$, Hydraulic Research Division and Suralco Ltd aluminum company (unpublished) ${ }^{7}$ and J. Mol and P. Ouboter (unpublished) ${ }^{10}$. In the period 1965-1967, water transparency increased in the reservoir ${ }^{3}$, dissolved oxygen concentration increased in the epilimnion ${ }^{5}$, and conductivity was low in surface water and high near the reservoir bottom as a result of decomposition of drowned forest vegetation and subsequent release of electrolytes ${ }^{4}$. The hypolimnion oxygen concentration decreased after spraying of water hyacinth with herbicide and subsequent decomposition of dead water plants on reservoir bottom ${ }^{6}$. In the months June-October 1985, hypolimnion water was anoxic ${ }^{9}$. The $\mathrm{pH}_{\text {of deep hypolim- }}$ nion water (20-25 m) was low (5.5-6.3 in 1981 and 4.3-5.2 in 1985) compared to surface water ${ }^{8}$.

\begin{tabular}{|c|c|c|c|c|c|c|c|c|c|}
\hline & $\begin{array}{c}\text { Within-year } \\
\text { water level } \\
\text { variation }(\mathrm{m})\end{array}$ & $\begin{array}{l}\text { Secchi-disk } \\
\text { transparency } \\
\text { (m) }\end{array}$ & $\begin{array}{l}\text { Conductivity } \\
(0-5 \mathrm{~m}) \\
\left(\mu \mathrm{S} . \mathrm{cm}^{-1}\right)\end{array}$ & $\begin{array}{c}\mathrm{pH} \\
(0-5 \mathrm{~m})\end{array}$ & $\begin{array}{c}\text { Diss. } \\
\text { oxygen } \\
(0-5 \mathrm{~m}) \\
\left(\mathrm{mg} . \mathrm{L}^{-1}\right) \\
\end{array}$ & $\begin{array}{c}\text { Diss. oxygen } \\
(10-15 \mathrm{~m}) \\
\left(\mathrm{mg} . \mathrm{L}^{-1}\right)\end{array}$ & $\begin{array}{c}\text { Diss. oxygen } \\
(20-25 \mathrm{~m}) \\
\left(\mathrm{mg} \cdot \mathrm{L}^{-1}\right)\end{array}$ & $\begin{array}{c}\text { Temperature } \\
(0-5 \mathrm{~m}) \\
\left({ }^{\circ} \mathrm{C}\right)\end{array}$ & $\begin{array}{c}\text { Temperature } \\
(20-25 \mathrm{~m}) \\
\left({ }^{\circ} \mathrm{C}\right)\end{array}$ \\
\hline $\begin{array}{l}\text { Suriname River } \\
\text { at Pokigron }(\mathrm{km} \\
273)^{1}\end{array}$ & $2.8-4.5^{2}$ & $0.5-1.9$ & $16-36$ & $5.1-6.0$ & $6.0-7.9$ & & & $25.0-33.4$ & \\
\hline $\begin{array}{l}\text { Forest streams } \\
\text { (tributaries to } \\
\text { Suriname River) }^{1}\end{array}$ & $?$ & $0.5-1.2$ & $30-85$ & $5.5-6.9$ & $4.2-7.4$ & & & $24.4-28.6$ & \\
\hline $\begin{array}{l}\text { Brokopondo } \\
\text { Reservoir at } \\
\text { Afobaka: }\end{array}$ & & & & & & & & & \\
\hline $1965-1967^{1}$ & $1.0-8.9$ & $0.5-2.7^{3}$ & $30(-260)^{4}$ & $5.4-5.8$ & $0.0-6.0^{5}$ & & 0.0 & $27.5-34.5$ & $25.0-26.0$ \\
\hline $1968-1969$ & $3.1-5.7$ & $2.0-3.4$ & & $5.5-6.3$ & 4.5 & & 3.2 & $28.0-32.0$ & $26.5-28.5$ \\
\hline 1970 & 3.2 & $2.5-3.0$ & & $5.9-6.0$ & 5.0 & & $0.6^{6}$ & $28.5-31.5$ & $26.5-28.5$ \\
\hline 1975 & 4.4 & $1.5-3.3$ & $30-70$ & $5.4-7.0$ & 5.2 & & 1.2 & $28.0-32.0$ & $26.0-28.5$ \\
\hline $1981^{7}$ & & $2.5-3.0$ & $17-31$ & $6.2-7.8^{8}$ & 6.4 & 3.3 & 1.4 & $29.3-31.2$ & $27.9-28.5$ \\
\hline $1985^{7}$ & & $2.5-4.0$ & $23-44$ & $5.0-5.7^{8}$ & 5.7 & 3.1 & $1.2^{9}$ & $28.0-31.3$ & $27.4-29.0$ \\
\hline $2004^{10}$ & & $1.6-3.0$ & $27-33$ & $6.7-7.3$ & 7.0 & & & $29.1-33.1$ & \\
\hline
\end{tabular}


vegetation removal was not carried out and many hard-wood trees had a height of 20-30 m (Donselaar, 1989), approximately $70 \%$ of Brokopondo Reservoir still had tree trunks emerging from the water in 2005 (J.H. Mol pers. observation).

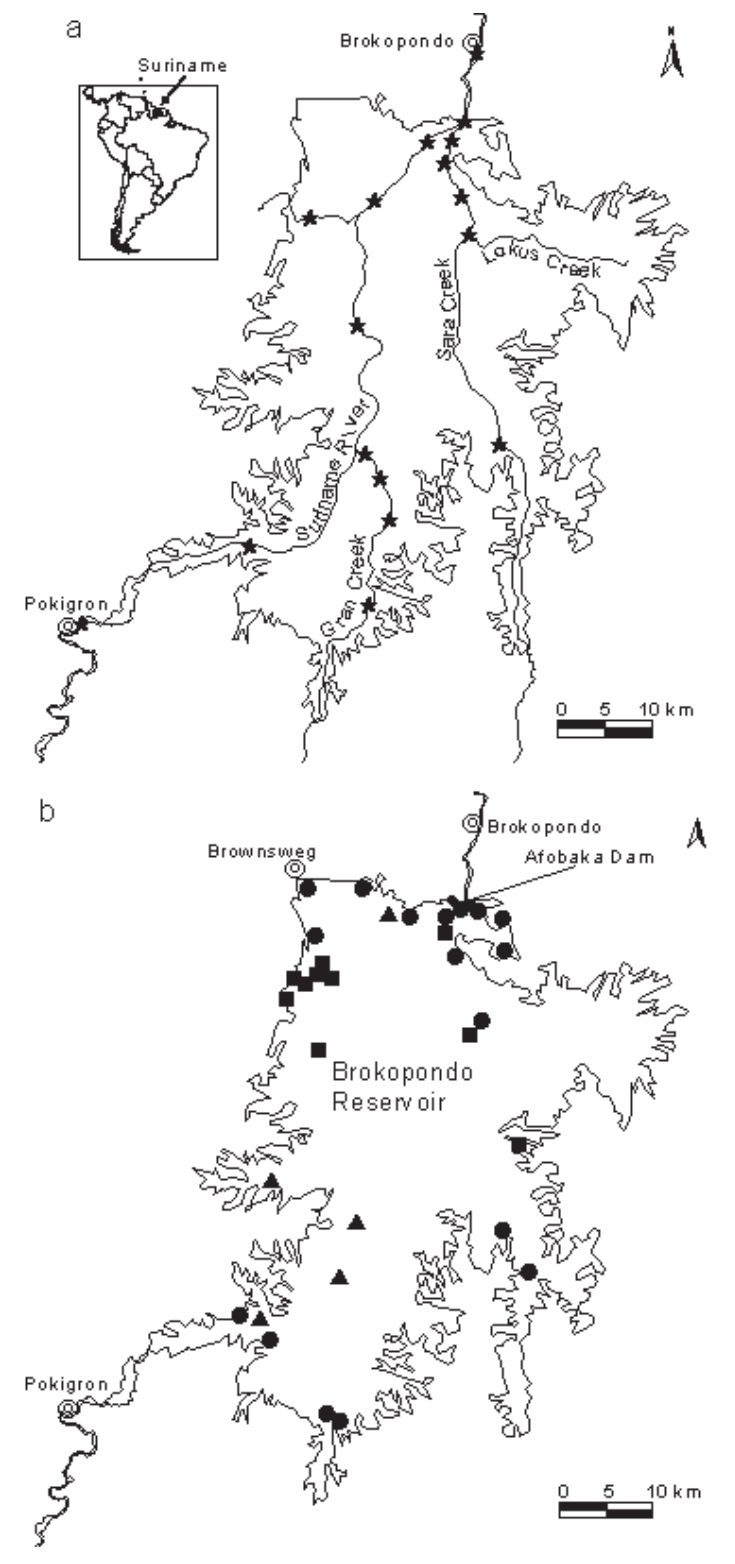

Fig. 1. Location and morphometry of Brokopondo Reservoir in Suriname showing fish sampling sites. (a) Former courses of the Suriname River and tributary streams in Brokopondo Reservoir area with pre-impoundment sampling sites (19631964; stars); outline of future Brokopondo Reservoir in grey. (b) Brokopondo Reservoir with sampling sites of fish surveys during filling stage (1965-1967; dots) and post-impoundment stage ([1978; triangles] and [2002-2005; squares]). The numerous small islands in the reservoir are not shown.
Some 5000 Maroons (descendants of escaped slaves) lived in the area inundated by the reservoir before its filling. These tribal people made a living from subsistence fishery, hunting and slash-and-burn agriculture. The maroons were relocated in new villages along the Suriname River above and below the reservoir (Leentvaar, 1973). The largest village in the area is Brownsweg (approximately 3000 inhabitants) at the northwest corner of the reservoir (Fig. 1). Other than small agricultural plots the only industries around the lake are logging and, since 1990, small-scale gold mining. No substantial fishery has developed on the reservoir during its 40-year existence: fishing on a commercial scale is non-existent and subsistence and sport fishing are little developed (e.g. Kapetsky, 1978; Richter \& Nijssen, 1980).

Fish surveys in the Brokopondo Reservoir area before and after closure of the dam

We analyzed fish collections from the pre-impoundment (1963-1964), filling (1966-1967) and post-impoundment (1978 and 2002-2005) phases of reservoir development.

In 1963-1964, Boeseman (1964) collected approximately 13,000 fishes of the Suriname River and its tributaries in the area of the future Brokopondo Reservoir. Boeseman used diverse sampling devices such as seine, fish trap, cast net, hook-and-line and even explosives, but he collected most fishes with fish poison (Boeseman, 1964). Although Boeseman (1964) presented a tentative and incomplete list of fish genera of the Suriname River and certain taxa in his collection were studied in taxonomic revisions (e.g. Boeseman, 1968, 1971, 1982; Nijssen, 1970; Géry, 1972; Mees, 1974; Kullander \& Nijssen, 1989), his large collection of Suriname River fishes was never studied in its entirety.

In the filling stage (1964-1967), the fish fauna of Brokopondo Reservoir was studied by Mees (1967) and Nijssen $(1967,1969)$.

In the post-impoundment stage, the fish fauna and fishery potential of Brokopondo Reservoir was studied in 1978 by Kapetsky (1978) and Richter \& Nijssen (1980). Kapetsky (1978) published the results of one successful rotenone sample. Richter \& Nijssen (1980) published the results of two gill net samples (open water habitat) and two rotenone samples (shore habitat). Our own collecting efforts in 2002-2005 were realized 40 years after closing of the dam and 34 years after the reservoir was filled.

\section{Sampling procedures, fish identification and analyses}

Eleven surveys of the fish fauna of Brokopondo Reservoir were conducted from April 2002 to February 2005. Fishes were collected in the eastern and northwestern part of the reservoir (Fig. 1). We distinguished four aquatic habitats: open water, sheltered bay, forested shore, and beach. The open water habitat still had numerous dead tree trunks emerging from the water surface, but wind action often resulted in turbulent water and large waves. Sheltered bays also had many dead tree trunks, but less wind and most of the time calm water. The forested shore habitat was found at the periphery of Brokopondo Reservoir where terra firme rainforest is bordered by a periodically flooded zone with dead bushes, woody debris and, locally, 
clumps of submerged macrophytes in shallow water (up to 1.5 $\mathrm{m}$ in depth). Beaches of firm laterite rock substrate or sand were especially abundant in wave-exposed areas on islands where woody debris was washed away by wave action.

In the off-shore area (open water and sheltered bays), we collected fishes with 2 sets of 10 experimental gill nets (each gill net $25 \mathrm{~m}$ long and $2.5 \mathrm{~m}$ deep) with knot-to-knot mesh-sizes of $10,15,20,25,30,35,40,50,60$ and $70 \mathrm{~mm}$. The gill nets were attached to dead trees to prevent the nets from drifting away. Gill nets were set both during the night and during the day. A sample corresponded to 12 hours fishing with 1 set of 10 gill nets at a specific sampling station (e.g. one set of gill nets was placed in bay $x$ for 12 hours [sample 1] and the next day this set of gill nets was moved to a different bay $y$ for a second sample of bay fishes). It is known that gill nets are selective to fish, but the use of a large range of meshes of close dimension and the sampling in every hour of the day-night cycle reduce that bias. The beach habitat was sampled with $25-\mathrm{m}$ long seine nets (2 and $10 \mathrm{~mm}$ knot-to-knot mesh). The shore habitat was sampled with $6.6 \%$ rotenone in concentration of approximately $0.25 \mathrm{~g} \mathrm{~m}^{-2}$ in five coves with an estimated surface area of 300 , $300,530,600$ and $1600 \mathrm{~m}^{2}$ (maximum depth $1.5 \mathrm{~m}$ ). The coves were blocked off with two block nets (length $25 \mathrm{~m}$, depth $3 \mathrm{~m}$, knot-to-knot mesh size $2 \mathrm{~mm}$ ) attached $25 \mathrm{~cm}$ above the water surface to prevent jumping fish from escaping. Fishes were collected in the sampling area at 2 and 12 hours after poisoning.

Fishes were transported to base camp where they were identified, measured to the nearest millimeter standard length, and weighed to the nearest $0.1 \mathrm{~g}$. Representative specimens were initially preserved in $4 \%$ formaldehyde, and then later transferred to $70 \%$ ethanol for long term storage at the National Zoological Collection of Suriname (NZCS) in Anton de Kom University of Suriname, Paramaribo. The stomach contents of fish species from the open water habitat were examined in the field (Serrasalmus rhombeus and Cichla ocellaris) or in the laboratory using a Wild M5-53340 stereo microscope. Stomach fullness was estimated as $0,5,25,50,75$ or $100 \%$. Stomachs with fullness $\geq 50 \%$ were retained for diet analysis. Food items were identified and grouped in eight categories: zooplankton (Cladocera, Ostracoda and Copepoda), Culicinae pupae, shrimps, fish, fine detritus, terrestrial invertebrates, terrestrial vertebrates and a rest group. The volume of food items was estimated as percentage of the total stomach contents and then adjusted for stomach fullness in all further calculations.

Fishes of the Suriname River prior to closure of the dam were studied in the 1963-1964 collection of M. Boeseman in Naturalis Museum (formerly Rijks Museum voor Natuurlijke Historie, RMNH), Leiden, the Netherlands. For each sample, we identified the species and then counted the number of specimens per species and measured total wet mass per species to the nearest $0.1 \mathrm{~g}$ and standard length to the nearest millimeter.

Fishes were identified with keys in general taxonomic treatises like Géry (1977) and Burgess (1989), regional contributions like Eigenmann (1912), Planquette et al. (1996), Keith et al. (2000) and Le Bail et al. (2000) and taxonomic surveys specific to Suriname like Nijssen (1970), Boeseman (1968, 1971, 1982), Kullander \& Nijssen (1989), and many others. Maxi- mum standard length of species was obtained mainly from Reis et al. (2003). Categorization of habitat use of adults in riverine conditions was based on personal observations (JHM and PEO). Analysis of differences in community structure was based on relative abundance, the proportions in numbers and biomass of each species in the samples. Proportions (in biomass or numbers) of total sample belonging to $i$ th species $\left(p_{i}\right)$ were used to calculate species diversity with the Shannon-Wiener index (Krebs, 1989). Evenness $(J)$ was also calculated according to Krebs (1989).

\section{Statistical analysis}

Because raw numbers or biomass cannot be compared among samples taken with different sampling methods, we converted fish numbers and biomass to proportions of the total sample (i.e. relative abundance of the species) to assess semi-quantitatively differences among habitats (e.g. shore and open water) and collection periods (i.e. Suriname River 19631964, Brokopondo Reservoir 1978 and Brokopondo Reservoir 2002-2005). Fish community structure was described by composition at species and family level (in number of specimens and biomass), number of species, species diversity $(H)$, and equitability $(J)$. Differences in fish community structure among reservoir habitats in 2002-2005 were assessed at the family level by ANOVA with arcsine-transformed proportions after testing for normality and homogeneity of variances. Differences in fish community structure between Suriname River (1963-1964) and Brokopondo Reservoir (2002-2005) and between Brokopondo Reservoir in 1978 and 2002-2005 were assessed with Wilcoxon's signed-ranks test using average proportions. Differences in relative biomass of fish species between Suriname River (1963-1964) and Brokopondo Reservoir (2002-2005) were assessed with Student's $t$-test after testing for normality. Significance was accepted when $p<0.05$.

\section{Results}

\section{The fish fauna of Suriname River before the closure of the dam}

We counted 12842 fishes with a wet biomass of approximately $176.4 \mathrm{~kg}$ in 168 species in Boeseman's 1963-1964 collection of fishes of the Suriname River and its tributaries in the area of the future Brokopondo Reservoir (Appendix 1, Table 2). Species diversity (numbers/biomass) of the Suriname River fish fauna was high (4.11/3.76), as was evenness (0.80/0.74). In number of individuals and species, the riverine fauna was dominated by small-sized fishes $(\leq 20 \mathrm{~cm} \mathrm{SL})$ (Table 3$)$, but there was no singly dominant species. The cichlid Geophagus surinamensis was the most abundant species (5.7\%), but 15 other species also had a relative abundance of 2-5\%. In biomass the fish fauna was dominated by large $(\geq 30 \mathrm{~cm} \mathrm{SL})$ catfishes Brachyplatystoma filamentosum (17.0\%; a single specimen of $170 \mathrm{~cm}$ TL with conservatively estimated wet mass of $30 \mathrm{~kg}$ ), Pseudoplatystoma fasciatum (4.5\%), Pimelodus ornatus (2.9\%) and Platydoras dentatus (2.3\%), and the medium-sized characoids C. cyprinoides (6.6\%), H. unimaculatus ( $4.5 \%), A$. microlepis $(2.3 \%)$ and Brycon falcatus $(2.0 \%)$ and cichlids $G$. surinamensis (4.9\%) and C. saxatilis (2.1\%) (Appendix 1, Table $3)$. Species were relatively evenly distributed over habitat 
categories, although surface fishes were somewhat under represented (Table 3). Habitat generalists were dominant in number of individuals and, to a lesser extent, in biomass. Large catfishes from the bottom of the main river channel were dominant in biomass. Four additional species, absent in the 1963-1964 collection of Boeseman, were caught in the Brokopondo Reservoir area before or after closure of the dam: Plagioscion squamosissimus, Serrasalmus eigenmanni, Micropoecilia bifurca and Megalops atlanticus (Appendix 1).

\section{The fish fauna of Brokopondo Reservoir in 1967 and 1978}

In 1967, four years after closure of the dam, Nijssen (1967, 1969) collected 62 fish species in Brokopondo Reservoir (Appendix 1, Table 2), but the reservoir fish fauna was clearly still in transition as shown by conspicuous fish species that were collected in 1967 but not in 1978 and 2002-2005, e.g. Hoplerythrinus unitaeniatus, two hatchet fishes
(Gasteropelecidae), electric eel (Electrophorus electricus), the gymnotiform knifefish Gymnotus carapo, the cichlids $A$. tetramerus, A. steindachneri and N. anomala, and some medium to large-sized catfishes (Callichthys callichthys, Megalechis thoracata, Trachelyopterus galeatus, Hemisorubim platyrhynchos, Pseudoplatystoma fasciatum and Batrachoglanis raninus). In 1978, 35 fish species were recorded from Brokopondo Reservoir (Kapetsky, 1978; Richter \& Nijssen, 1980; Appendix 1, Table 2); species diversity (numbers/biomass) was $1.82 / 2.04$ and evenness was $0.75 / 0.61$. The open water community had only 11 species, low species diversity 1.49/0.46 (numbers/biomass), and evenness 0.62/0.19. The shore community had 31 species, species diversity $1.48 /$ 2.26 (numbers/biomass), and evenness 0.60/0.65.

\section{The fish fauna of Brokopondo Reservoir in 2002-2005}

In 2002-2005, we collected 6474 fishes with a biomass of

Table 2. Fish community parameters for Suriname River (pre-impoundment 1963-1964) and four different habitats in Brokopondo Reservoir in 1966-1967, 1978 and 2002-2005. Biomass of shore fish community in 1978 is given in $\mathrm{kg} \mathrm{per} \mathrm{ha}^{1}$.

\begin{tabular}{|c|c|c|c|c|c|c|}
\hline & & $\begin{array}{l}\text { Number of } \\
\text { specimens }\end{array}$ & $\begin{array}{c}\text { Biomass } \\
(\mathrm{kg})\end{array}$ & $\begin{array}{c}\text { Number of } \\
\text { species }\end{array}$ & $\begin{array}{l}\text { Species diversity } H \\
\text { (numbers / biomass) }\end{array}$ & $\begin{array}{c}\text { Evenness } J \text { (numbers / } \\
\text { biomass) }\end{array}$ \\
\hline Suriname River 1963-1964 & & 12842 & 176.4 & 172 & $4.11 / 3.76$ & $0.80 / 0.74$ \\
\hline Brokopondo Reservoir 1966-1967 & & - & - & 62 & - & - \\
\hline \multirow[t]{3}{*}{ Brokopondo Reservoir 1978} & Open water & 301 & 67.9 & 11 & $1.49 / 0.46$ & $0.62 / 0.19$ \\
\hline & Shore & 2540 & $26.0^{1}$ & 31 & $1.48 / 2.26$ & $0.60 / 0.65$ \\
\hline & Total & 2841 & - & 35 & $1.82 / 2.04$ & $0.75 / 0.61$ \\
\hline \multirow[t]{5}{*}{ Brokopondo Reservoir 2002-2005 } & Open water & 1511 & 110.9 & 10 & $0.88 / 0.62$ & $0.38 / 0.27$ \\
\hline & Shore & 2308 & 20.5 & 27 & $2.29 / 2.43$ & $0.70 / 0.74$ \\
\hline & Bay & 2020 & 110.5 & 23 & $1.58 / 1.51$ & $0.51 / 0.48$ \\
\hline & Beach & 636 & 5.2 & 11 & $1.31 / 1.81$ & $0.54 / 0.75$ \\
\hline & Total & 6475 & 247.1 & 41 & $2.17 / 1.53$ & $0.60 / 0.42$ \\
\hline
\end{tabular}

Table 3. Size (maximum Standard Length; cm) distribution of fish faunas of Suriname River Basin (1963-1964) and Brokopondo Reservoir (2002-2005), and habitat distribution of fishes of Suriname River Basin and representation of fishes from riverine habitats in Brokopondo Reservoir; proportions in number of specimens N, wet mass M, number of species (/ \%) and richness (S). The habitat generalist category contains species well represented in more than one habitat (main channel, tributary, rapid $)^{1}$. The tributary-leaf litter/debris category contains species from leaf litter and woody debris habitats ${ }^{2}$.

\begin{tabular}{|c|c|c|c|c|c|c|}
\hline & \multicolumn{3}{|c|}{ Suriname River (1963-1964) } & \multicolumn{3}{|c|}{ Brokopondo Reservoir (2002-2005) } \\
\hline & $\mathrm{N} \%$ & $\mathrm{M} \%$ & $\mathrm{~S}(/ \%)$ & $\mathrm{N} \%$ & $\mathrm{M} \%$ & $\mathrm{~S}(/ \%)$ \\
\hline \multicolumn{7}{|l|}{ Size category $\left(\mathrm{SL}_{\max }\right.$ in $\left.\mathrm{cm}\right)$} \\
\hline $1-10$ & 43.41 & 10.35 & $69(/ 40.1)$ & 4.25 & 0.38 & $5(/ 13.5)$ \\
\hline $11-20$ & 29.14 & 21.87 & $46(/ 26.7)$ & 57.34 & 10.19 & $9(/ 24.3)$ \\
\hline $21-30$ & 14.97 & 26.72 & $26(/ 15.1)$ & 21.83 & 13.60 & $12(/ 32.4)$ \\
\hline $31-40$ & 8.65 & 11.96 & $13(/ 7.6)$ & 0.50 & 3.29 & $6(/ 16.2)$ \\
\hline $41-50$ & 2.70 & 4.46 & $5(/ 2.9)$ & 15.94 & 71.38 & $3(/ 8.1)$ \\
\hline $51-60$ & 0.24 & 0.87 & $3(/ 1.7)$ & 0.00 & 0.00 & 0 \\
\hline$>60$ & 0.81 & 24.19 & $8(/ 4.6)$ & 0.17 & 1.17 & $2(/ 5.4)$ \\
\hline unknown & 0.17 & 0.01 & $2(/ 1.2)$ & 0.00 & 0.00 & 0 \\
\hline \multicolumn{7}{|l|}{ Habitat category } \\
\hline Generalist $^{1}$-surface & 5.86 & 4.84 & $6(/ 3.5)$ & 38.12 & 7.84 & $3(/ 8.1)$ \\
\hline Generalist-column & 42.98 & 27.19 & $22(/ 12.8)$ & 20.87 & 7.34 & $12(/ 32.4)$ \\
\hline Generalist-bottom & 6.34 & 7.87 & $14(/ 8.1)$ & 21.59 & 6.87 & $6(/ 16.2)$ \\
\hline Main channel-surface & 1.54 & 2.80 & $5(/ 2.9)$ & 0.23 & 0.23 & $2(/ 5.4)$ \\
\hline Main channel-column & 4.09 & 9.25 & $16(/ 9.3)$ & 15.82 & 76.81 & $8(/ 21.6)$ \\
\hline Main channel-bottom & 3.15 & 30.33 & $12(/ 7.0)$ & 0.05 & 0.83 & $2(/ 5.4)$ \\
\hline Tributary-surface & 5.12 & 0.69 & $6(/ 3.5)$ & 0.00 & 0.00 & 0 \\
\hline Tributary-column & 9.04 & 2.69 & $19(/ 11.0)$ & 3.08 & 0.04 & $2(/ 5.4)$ \\
\hline Tributary-bottom & 7.53 & 4.57 & $12(/ 7.0)$ & 0.02 & 0.00 & $1(/ 2.7)$ \\
\hline Tributary-leaf litter/debris ${ }^{2}$ & 3.97 & 0.94 & $20(/ 11.6)$ & 0.00 & 0.00 & 0 \\
\hline Rapids-column & 3.20 & 4.24 & $8(/ 4.6)$ & 0.00 & 0.00 & 0 \\
\hline Rapids-bottom & 2.46 & 2.42 & $12(/ 7.0)$ & 0.00 & 0.00 & 0 \\
\hline migratory & 0.32 & 0.48 & $4(/ 2.3)$ & 0.00 & 0.00 & 0 \\
\hline unknown & 4.49 & 2.12 & $16(/ 9.3)$ & 0.25 & 0.05 & $1(/ 2.7)$ \\
\hline
\end{tabular}


$247.1 \mathrm{~kg}$ in 37 species in 54 samples in Brokopondo Reservoir (Appendix 1, Table 2). An asymptote in the species accumulation curve was reached in 2004, and four samples in February 2005 yielded no additional species. Species diversity was $2.17 /$ 1.53 (numbers/biomass) and evenness 0.60/0.42. In 2000, Mol et al. (2001) caught four additional species in Brokopondo Reservoir and thus we estimate that 41 fish species occurred in the reservoir (Appendix 1). We collected no exotic or invasive fish species in Brokopondo Reservoir; i.e. all reservoir species were also collected in Suriname River in 1963-1964 (Appendix 1).

At the family level (Appendix 1), fish community structure was significantly different among four habitats of Brokopondo Reservoir. Anostomids were found in higher relative abundance (ANOVA; $p<0.001$ ) and relative biomass $(p<0.05)$ in sheltered bays than in shore habitat and they were not collected in open water and beach habitats. The open water and sheltered bay habitats had a higher relative abundance of Characidae than the shore habitat $(p<0.05)$. Hemiodontids were found in higher relative abundance $(p<0.0001)$ and biomass $(p<0.01)$ in open water than in beach, shore and bay habitats. Serrasalmids (mainly Serrasalmus rhombeus) were found in higher relative abundance $(p<0.0001)$ and biomass $(p<0.00001)$ in open water and sheltered bays than in shore and beach habitats. Cichlids were found in higher relative abundance $(p<0.0001)$ and biomass $(p$ $<0.0001)$ in shore habitat than in beach habitat and in beach habitat they had a higher relative abundance and biomass than in open water and sheltered bays. Erythrinidae (Hoplias malabaricus), Doradidae (Platydoras dentatus), Loricariidae (Hypostomus surinamensis and Loricariichthys maculatus) and Sternopygidae (Sternopygus macrurus) were collected only in shore habitat.

We collected 1511 fishes with a total wet biomass of 110.9 $\mathrm{kg}$ in 17 samples in open water habitat (Appendix 1, Table 2). The fish community of open water had only 10 species (with 2 species, Curimata cyprinoides and Myleus rubripinnis, represented by a single specimen), low species diversity ( 0.88 / 0.62 ; numbers/biomass) and low evenness (0.38/0.27). The open-water fish community was dominated by the piscivores S. rhombeus ( $86.0 \%$ of fish biomass) and Acestrorhynchus microlepis (3.6\%), and their main prey Bryconops melanurus (66.8\% of specimens caught) and the two Hemiodus species ( $2.6 \%$ of numbers). B. melanurus fed near the surface on zooplankton, Culicinae pupae and terrestrial invertebrates (Table 4; Fig. 2). Hemiodus fed near the bottom on fine, flocculent detritus with uniform particle size, while Cichla ocellaris preyed on benthic shrimps (Macrobrachium). Acestrorhynchus preyed near the surface on B. melanurus. $S$. rhombeus showed opportunistic feeding behavior in preying on Hemiodus argenteus and H. unimaculatus near the bottom, B. melanurus near the surface and also showing cannibalism in eating juveniles $(85-135 \mathrm{~mm})$. When, in June 2002, a pack of white-lipped peccaries (Tayassu pecari) drowned while crossing the reservoir in rough weather, S. rhombeus also fed opportunistically on these peccaries.

The fish community of sheltered bays (2020 fishes, 110.5 $\mathrm{kg}$; 25 samples) had 23 species, species diversity of $1.58 / 1.51$ (numbers/biomass) and low evenness of 0.51/0.48 (Appendix 1 , Table 2). The fish species that dominated the community in numbers or biomass were the same species that dominated the open water habitat fish community ( $S$. rhombeus, $B$. melanurus, A. microlepis and the two Hemiodus species), but a number of other species were also well represented (e.g. Leporinus fasciatus, Schizodon fasciatus, Chalceus macrolepidotus, Moenkhausia grandisquamis, Poptella brevispina, Roeboides thurni, Curimata cyprinoides, Prochilodus rubrotaeniatus, Myleus rubripinnis, C. ocellaris and Plagioscion squamosissimus).

In five rotenone samples in shore habitat we collected 2308 fishes (20.5 kg) in 27 species (Appendix 1, Table 2). Both species diversity (2.29/2.43; numbers/biomass) and evenness $(0.70$ / 0.74 ) were high. Total fish biomass amounted to $66.5 \pm 59.9 \mathrm{~kg}$ $\mathrm{ha}^{-1}$ (mean \pm SD; range: $\left.16.6-164.8 \mathrm{~kg} \mathrm{ha}^{-1}\right)$. The shore community was dominated by $H$. argenteus and seven cichlids: Geophagus surinamensis, Guianacara owroewefi, Cichlasoma bimaculatum, Krobia guianensis, two Crenicichla species, and juvenile C. ocellaris. Other species well represented in the shore community were the anostomids Leporinus friderici and L. fasciatus, B. melanurus, Hemigrammus boesemani (in submerged macrophytes), Bivibranchia simulata, C. macrolepidotus, H. malabaricus, and the loricariid catfish L. maculatus. In clumps of submerged macrophytes, we collected early stages of $S$. rhombeus $(30 \pm 4.29$ $\mathrm{mm}, 1.0 \pm 0.31 \mathrm{~g} ; \mathrm{n}=17$ ). Small-sized B. melanurus ( 2 specimens of 37 and $39 \mathrm{~mm} \mathrm{SL} ; \mathrm{n}=144$ ) were also collected in the shore habitat; in open water B. melanurus had SL $>60 \mathrm{~mm}(\mathrm{n}=1010)$.

We collected 636 fishes $(5.3 \mathrm{~kg}$; 7 samples) in 11 species in beach habitat (Appendix 1, Table 2). Species diversity was $1.31 / 1.81$ (numbers/biomass) and evenness was $0.54 / 0.75$. The beach community was dominated by $H$. argenteus, $B$. melanurus, $M$. grandisquamis, and the cichlids $C$. ocellaris (juveniles) and G. surinamensis.

\section{Comparison of the fish faunas of Suriname River and Brokopondo Reservoir}

At the family level (Appendix 1) fish community structure was significantly different among Suriname River (1963-1964) and Brokopondo Reservoir (2002-2005) both in relative abundance (Wilcoxon's signed-rank test; $p=0.011$ ) and biomass $(p=0.002)$. The characoid families Anostomidae, Curimatidae and Gasteropelecidae decreased in relative abundance and biomass after damming, while Hemiodidae and Serrasalmidae (mainly S. rhombeus) increased in numbers and biomass. Brokopondo Reservoir had almost no Gymnotiformes (only S. macrurus was collected in the reservoir) and Siluriformes; all families in these orders were negatively affected by the dam. With the exception of two small species from leaf litter in tributaries (Nannacara anomala and Apistogramma steindachneri), cichlids were less affected by the change from riverine to reservoir conditions.

Of 172 species known to have occurred in the Suriname River in the reservoir area only 41 were collected in Brokopondo Reservoir in 2002-2005 (Appendix 1). When compared to the original Suriname River fish fauna, fish communities of Brokopondo Reservoir showed low species diversity and evenness (Table 2) with dominance of only a few species (Fig. 3). Brokopondo Reservoir had a low proportion 


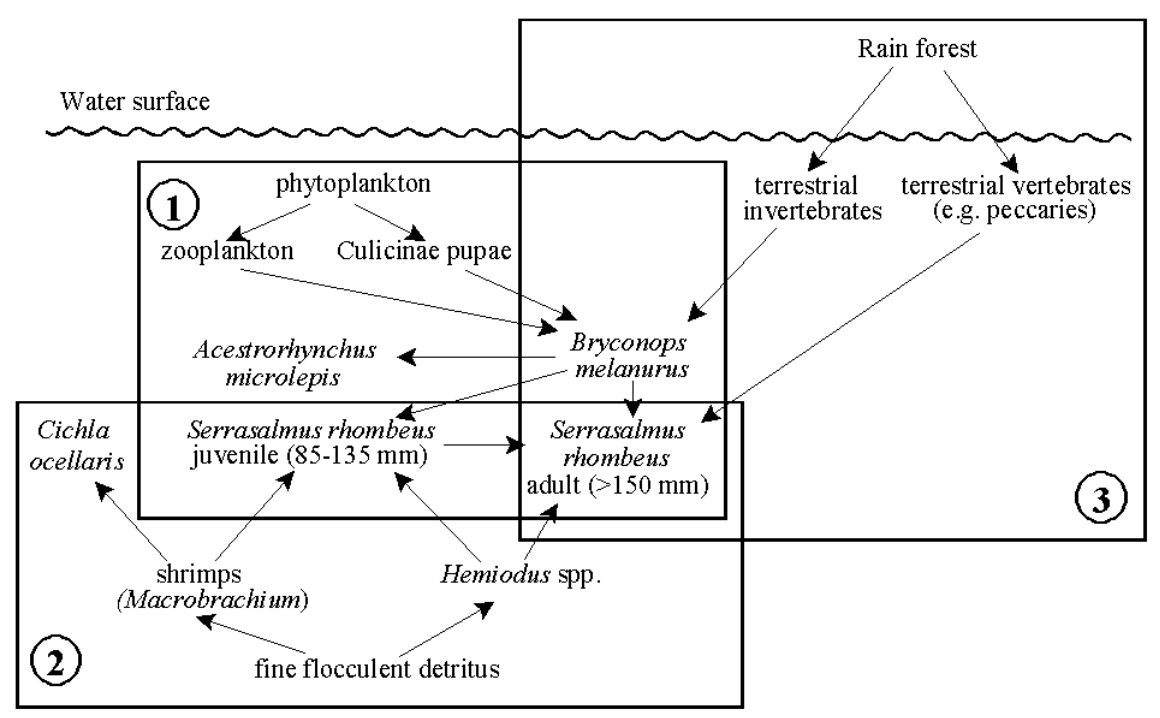

Reservoir bottom

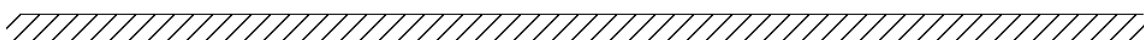

Fig. 2. Food web of the open-water habitat of Brokopondo Reservoir based on fish stomach content analysis. Food chains are based on autochthonous autotrophic production (1), fine, flocculent detritus of unknown origin (2) and, to a lesser extent, allochthonous production of the rain forest (3).

of small-sized species and individuals $(\leq 10 \mathrm{~cm} \mathrm{SL})$ and a low biomass of large-sized ( $>60 \mathrm{~cm} \mathrm{SL}$ ) fishes compared to the Suriname River fish fauna (Table 3), but these differences in size-class distribution between riverine and reservoir faunas were not significant (Wilcoxon's signed ranks test; $p>0.05$ ). B. melanurus (t-test, $p<0.0001)$ and G. surinamensis $(p<$ 0.01 ) had a lower average wet mass in Brokopondo Reservoir than in Suriname River before closure of the dam (Table 5). Large piranhas $S$. rhombeus $>300 \mathrm{~mm}$ were rare in Brokopondo Reservoir ( $0.8 \%$ of 762 specimens; $\mathrm{SL}_{\max } 340 \mathrm{~mm}$ ) as compared to the Suriname River before closure of the dam $(6.8 \%$ of 74 specimens; SL 385 mm; Géry, 1972).

Habitat generalists (e.g. B. melanurus, Hemiodus spp, and cichlids) and midwater species from the main river channel (e.g. S. rhombeus) were well represented in the fish fauna of Brokopondo Reservoir. In 57 species from tributary forest creeks, including 20 small-sized species from leaf litter and woody debris, only 3 survived in the reservoir (Table 3). All catfish and characoid species from riverine rapid habitat were lost from the area (Table 3).

\section{Comparison of the fish faunas of Brokopondo Reservoir in 1978 and 2002-2005}

The fish communities of Brokopondo Reservoir in 1978 and 2002-2005 were similar in number of species, species diversity and evenness (both the fish fauna of the reservoir in its entirety and the communities of open water and shore habitat). At the family level the structure of the fish communities of both open water (Wilcoxon's signed-rank test; $p$, numbers $=0.18 ; p$, biomass $=0.84)$ and shore habitat $(p$, numbers $=0.69 ; p$, biomass $=0.66)$ did not differ significantly between 1978 and 2002-2005 (Appendix 1). Both in 1978 and 2002-2005, the open water community was dominated by $B$. melanurus (numbers), S. rhombeus (numbers and biomass) and, to a lesser extent, Hemiodus (numbers only) (Fig. 3). Cichlids were dominant in number and biomass in the

Table 4. Diet of fishes from the open water habitat of Brokopondo Reservoir, 2002-2005. Data are average percentages by volume of each food item in stomachs with $>50 \%$ fullness (n). The rest category contains mainly aquatic insects (1.99\% in $B$. melanurus) and/ or chitinous remains ${ }^{1}$. In 6 stomachs of $A$. microlepis the prey species was Bryconops melanurus; in other stomachs the prey species could not be identified ${ }^{2}$. Zooplankton in stomachs of B. melanurus consisted mainly of Ostracoda (17.60\%) and Cladocera (7.03\%) with only few Copepoda $(0.11 \%)^{3}$. Detritus in Hemiodus argenteus and H. unimaculatus included $1.41 \%$ and $2.35 \%$ sand, respectively ${ }^{4,5}$. In one stomach of Serrasalmus rhombeus a crab $(1.26 \%)^{6}$ was present and in 6 stomachs the remains of white-lipped peccaries (Tayassu pecari) (e.g. hoofs, hair; 12.7\%) were found ${ }^{8}$; fish prey species identified from $S$. rhombeus stomachs were $B$. melanurus (3 stomachs), Hemiodus spp. (3 stomachs), Plagioscion squamosissimus (1 stomach) and S. rhombeus (1 stomach) ${ }^{7}$.

\begin{tabular}{|c|c|c|c|c|c|c|c|c|c|}
\hline Species & $\mathrm{n}$ & zooplankton & $\begin{array}{c}\text { Culicinae } \\
\text { pupae }\end{array}$ & shrimps & fish & $\begin{array}{c}\text { fine } \\
\text { detritus }\end{array}$ & $\begin{array}{c}\text { terrestrial } \\
\text { invertebrates }\end{array}$ & $\begin{array}{c}\text { terrestrial } \\
\text { vertebrates }\end{array}$ & rest group ${ }^{1}$ \\
\hline Acestrorhynchus microlepis & 11 & 0.57 & 0.00 & 0.00 & $96.00^{2}$ & 2.86 & 0.00 & 0.00 & 0.57 \\
\hline Bryconops melanurus & 52 & $24.74^{3}$ & 48.36 & 4.42 & 2.21 & 0.66 & 15.40 & 0.00 & 3.98 \\
\hline Hemiodus argenteus & 24 & 1.61 & 0.00 & 0.00 & 0.00 & $98.18^{4}$ & 0.00 & 0.00 & 0.21 \\
\hline Hemiodus unimaculatus & 8 & 0.00 & 0.00 & 0.00 & 0.00 & $97.77^{5}$ & 0.35 & 0.00 & 1.88 \\
\hline Serrasalmus rhombeus & 43 & 0.00 & 0.00 & $6.29^{6}$ & $77.04^{7}$ & 0.00 & 1.26 & $12.70^{8}$ & 2.70 \\
\hline Cichla ocellaris & 4 & 0.00 & 0.00 & 100.00 & 0.00 & 0.00 & 0.00 & 0.00 & 0.00 \\
\hline
\end{tabular}


more diverse shore community, but other species (miscellaneous group) were also abundant (Fig. 3). Fish biomass in the shore habitat was 17.4-31.5 kg ha-1 in 1978 (Kapetsky, 1978; Richter \& Nijssen, 1980) and 16.6-164.8 $\mathrm{kg} \mathrm{ha}^{-1}$ in 2002-2005 (or $16.6-69.4 \mathrm{~kg} \mathrm{ha}^{-1}$ when excluding the outlier $\left.164.8 \mathrm{~kg} \mathrm{ha}^{-1}\right)$.

\section{Discussion}

When comparing our results with studies of other Amazonian reservoirs, differences in sampling methods and status of taxonomic knowledge of regional fish faunas should be considered. The impact of Amazonian reservoirs on riverine fish faunas was studied by comparing pre- and post-impoundment faunas based on (size-selective) gill net samples in the main river channel and reservoir (e.g. Vieira, 1982; Novoa et al., 1991; Leite, 1993; Santos, 1995; Mérona et al., 2003), thus probably undersampling small-sized species and species from specific riverine (tributaries, rapids and floodplain lakes) and reservoir (shore) habitats. In the present study, fishes were collected by diverse methods, including rotenone, gill nets, seine and other devices (e.g. Boeseman, 1964), and in diverse habitats. However, large catfishes of mid-channel bottom habitat were undersampled in the present study.

In 1967, four years after closure of the dam, the fish fauna of Brokopondo Reservoir was still changing. S. rhombeus, $B$. melanurus and $C$. ocellaris were already 'abundant' in the reservoir (Nijssen, 1967, 1969), but only 26 in 62 species of the reservoir fauna in 1967 were collected during the present study. In 1978, reservoir fish communities had apparently achieved stable equilibrium because (1) number of species, species diversity and evenness were very similar in 1978 and 2002-2005, (2) in open-water and shore habitat community structure at the family level did not differ between 1978 and 2002-2005, (3) in both 1978 and 2002-2005, the open water was dominated by piranha $S$. rhombeus, B. melanurus, $A$. microlepis and two Hemiodus species, while the more diverse shore community was dominated by seven cichlids, and (4) fish biomass in the shore habitat was of the same order of magnitude in 1978 and 2002-2005. Chemical and biological events associated with the filling of a new reservoir such as anoxia, eutrophication, plankton blooms and colonization by fishes vary with characteristics of the inundated terrestrial vegetation, basin morphology, and duration of the filling stage (Baxter, 1977; Agostinho et al., 1999). Amazonian reservoirs stratify for long periods (Heide, 1982; Tundisi et al., 1993). By providing oxygen, outflow rates and residence times largely determine decomposition of the drowned vegetation and the aging process of the reservoir ecosystem (Tundisi et al., 1993). In Brokopondo Reservoir, with its long 26-month residence time, decomposition of inundated rainforest vegetation took approximately 4 years (Heide, 1982). However, physicochemical stabilization was further delayed by decomposition of a huge biomass of dead floating macrophytes, estimated at 470 ton dry mass per $\mathrm{km}^{2}$ (PandayVerheuvel, 1983), that sank to the reservoir bottom after spraying with herbicide in 1969. The time necessary to reach temporal stability in reservoir fish fauna was similar for Brokopondo (14 years) and Kariba (10 years; Balon, 1974) reservoirs. In Petit Saut Reservoir (French Guiana; residence time of 6 months), species composition of the fish fauna was still changing seven years after closure of the dam (Mérona, 2002).

The fish fauna of Brokopondo Reservoir was derived from the Suriname River fish fauna. With the exception of East Africa the tropics have few natural lakes with lacustrine fish species (Fernando \& Holèik, 1982) and the fish fauna of Amazonian reservoirs is mainly of riverine origin. In Brokopondo Reservoir, much like other Neotropical reservoirs (Araujo-Lima et al., 1995; Agostinho et al., 1999), the fish community of shore habitat had more species, higher species diversity and higher evenness than the open water community. This may be explained by (1) the greater structural complexity of shore habitat (woody debris, dead bushes, submerged macrophytes) compared to open water habitat and (2) the fact that most riverine fishes have experienced littoral-like conditions in their pre-impoundment habitat (e.g. floodplains) and thus tend to stay near the shore when colonizing reservoirs whereas only few species are preadapted to exploit the open water habitat (Fernando \& Holèik, 1982). Cichlids, which are known to thrive in tropical lakes and reservoirs (Fernando \& Holèik, 1982), were also dominant in the littoral of Brokopondo Reservoir.

The open water habitat of Brokopondo Reservoir had only ten fish species and, with the exception of Acestrorhynchus, all open water species were also collected in the shore habitat. The open-water species $S$. rhombeus, B. melanurus and $C$. ocellaris should probably return to shore periodically to spawn (e.g. Zaret, 1980) and their early stages and small juveniles were collected exclusively in the shore habitat. The important criterion of success as a pelagic open-water species is the ability to feed on zooplankton in the adult period (Fernando, 1994). Tropical freshwaters have only a small number of obligate zooplanktivorous fishes, mainly in the family Clupeidae. Clupeids

Table 5. Comparison of average wet mass per specimen (mean $\pm \mathrm{SD} ; \mathrm{g}$ ) of some dominant fish species in samples of Suriname River (1963-1964) and Brokopondo Reservoir (2002-2005). Number of samples in parentheses. Results of $t$-test are given. Measurements of wet mass of Suriname River fishes were taken 40 years after the specimens had been placed in ethanol, which is known to cause significant shrinkage of tissues; these values should be taken as minimum values ${ }^{1}$.

\begin{tabular}{lccc}
\hline Species & $\begin{array}{c}\text { Suriname River }^{1} \\
\text { (wet mass per specimen, g) }\end{array}$ & $\begin{array}{c}\text { Brokopondo Reservoir } \\
\text { (wet mass per specimen, g) }\end{array}$ & $p$ \\
\hline Bryconops melanurus & $8.3 \pm 4.0(31)$ & $5.5 \pm 1.1(45)$ & $<0.0001$ \\
Hemiodus argenteus & $18.6 \pm 7.0(9)$ & $13.8 \pm 8.8(21)$ & 0.1604 \\
Hemiodus unimaculatus & $28.2 \pm 27.7(21)$ & $25.2 \pm 13.4(32)$ & 0.6013 \\
Crenicichla saxatilis & $24.6 \pm 16.9(20)$ & $7.6 \pm 3.3(4)$ & 0.0618 \\
Geophagus surinamensis & $28.5 \pm 13.5(33)$ & $13.8 \pm 7.3(8)$ & 0.0052 \\
Guianacara owroewefi & $10.2 \pm 6.3(26)$ & $6.5 \pm 6.8(5)$ & 0.2381 \\
\hline
\end{tabular}




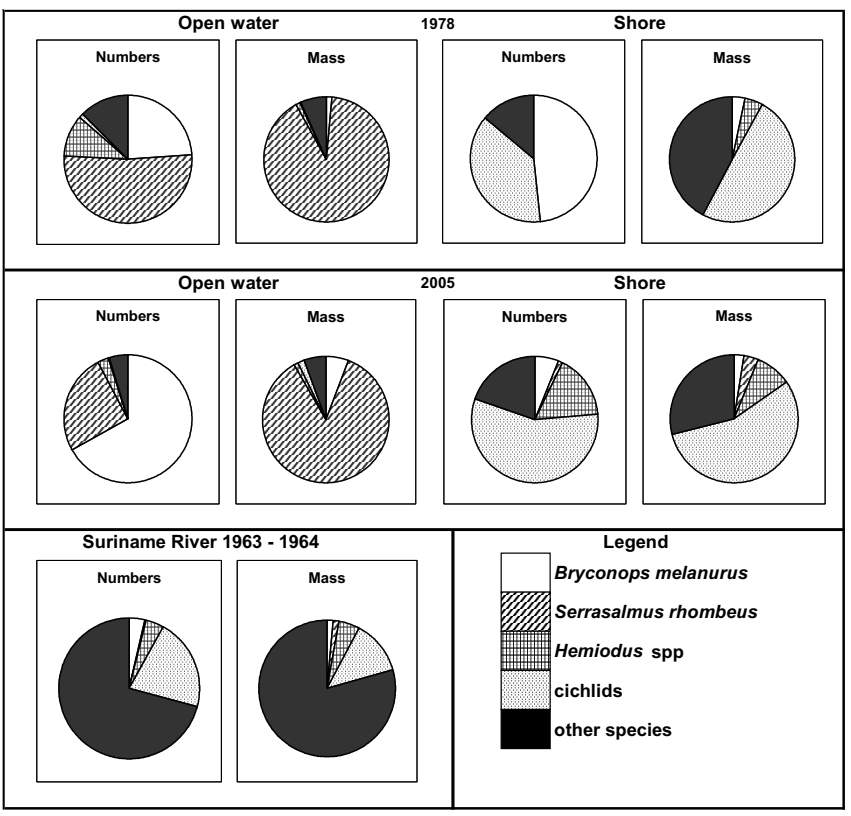

Fig. 3. Fish community structure of Suriname River prior to construction of the dam at Afobaka as compared to fish community structure in open water and forested shore habitats in Brokopondo Reservoir in 1978 (data in Richter \& Nijssen (1980) and Kapetsky (1978)) and 2002-2005 (present study). Average proportions (\%) in number of specimens and biomass are given for the most abundant species (-groups).

were abundant in open water of African reservoirs (Jackson et al., 1988), but the Amazonian freshwater clupeid Pellona was not abundant or even absent in Tucuruí (Leite, 1993), Samuel (Santos, 1995), Curuá-Una (Vieira, 1982) and Petit Saut (Mérona et al., 2003) reservoirs. The catfish Hypophthalmus was the only zooplanktivorous fish (Carvalho, 1980) that was abundant in Amazonian reservoirs, e.g. in Samuel (Santos, 1995) and Tucuruí (Ribeiro et al., 1995) reservoirs. Facultative zooplanktivorous fishes in Amazonian reservoirs included Anodus elongatus (Tucuruí Reservoir), Anchovia surinamensis (Tucuruí Reservoir), Auchenipterus nuchalis (Curuá-Una and Tucuruí reservoirs), Triportheus (Petit Saut Reservoir) and Hemiodus spp (Curuá-Una and Tucuruí reservoirs) (Ferreira, 1984; Mérona et al., 2001, 2003). The middle Suriname River had no freshwater clupeids nor Hypophthalmus (Appendix 1), whereas A. surinamensis (which probably spawns in the estuary), Triportheus and A. nuchalis did not survive in the reservoir and the two Hemiodus species fed exclusively on detritus. In Brokopondo Reservoir, B. melanurus was the only fish that fed on zooplankton in open water, but Culicinae pupae and terrestrial invertebrates were also a substantial component in its diet. Riverine Bryconops mainly fed on allochthonous invertebrates (e.g. Saul, 1975; Mérona et al., 2003) and the reduced body mass of $B$. melanurus in Brokopondo Reservoir as compared to riverine populations may indicate sub-optimal feeding and stunting in the reservoir. Adaptation to a new diet is well documented in reservoir fishes (Jackson et al., 1988), including Amazonian species (Mérona et al., 2001, 2003). In Petit Saut Reservoir, juvenile cichlids $K$. guianensis and C. saxatilis had thin bodies when feeding sub-optimally on small-sized zooplankton (Ponton \& Mérigoux, 2000). In the open water of Brokopondo Reservoir, S. rhombeus fed on shoals of pelagic Bryconops prey, but, piranhas from the reservoir showed reduced standard length as compared to riverine populations.

Food chains in open water of Brokopondo Reservoir were based on autochthonous autotrophic production, fine flocculent detritus of unknown origin and, to a lesser extent, allochthonous production of the rain forest. In Neotropical rivers, the main source of energy is allochthonous organic material (Araujo-Lima et al., 1995), whereas reservoirs are fundamentally autotrophic systems (Baxter, 1977). In reservoirs, allochthonous organic material is probably most important to shore fishes, but in the open water of Brokopondo Reservoir B. melanurus and S. rhombeus also fed to some extent on food from the forest. Heterotrophic activity based on the decomposition of inundated forest vegetation is dominant in the filling phase of a reservoir (Baxter, 1977; Heide, 1982). A great development of detritivorous fishes was observed in Guri (Novoa et al., 1991), Petit Saut (Mérona et al., 2003) and Itaipu (Agostinho et al., 1999) reservoirs. The high abundance of detritusfeeding Hemiodus in Brokopondo Reservoir showed that detritus-based food chains can also be important in later stages of reservoir development. Macrobrachium shrimps probably also fed on detritus in Brokopondo and Tucuruí (Tundisi et al., 1993) reservoirs. Relatively long autochthonous food chains in open water of Brokopondo Reservoir (involving phytoplankton and zooplankton, both rare in Suriname River) may partially explain high mercury concentrations in the top predator $S$. rhombeus (up to $4.6 \mu \mathrm{g} \mathrm{Hg}$ per g muscle tissue) as compared to much lower $\mathrm{Hg}$ levels in piranhas from contaminated rivers (Mol et al., 2001). At Tucuruí, high mercury levels were detected in reservoir fish (including piranha) and human hair (Aula et al., 1994).

In 172 fish species of the middle Suriname River only 41 were collected in Brokopondo Reservoir 40 years after closure of the dam. The middle reach of Suriname River in the reservoir area may be viewed as a zone with high habitat heterogeneity where headwater and coastal plain species overlap, resulting in high fish diversity. The serial discontinuity concept (Ward \& Stanford, 1983, 1995) predicts that a dam in middle reaches can have a large impact on riverine fish diversity. Agostinho et al. (1999) pointed out that an unavoidable effect of impoundment on the fish fauna is a shift in species composition and abundance, with extreme proliferation of some species and reduction or elimination of others. Jackson et al. (1988) argued that new African reservoirs after a few years had more fish species than were present in the river previous to impoundment, but, if true, this can only be explained by the introduction of exotic species. Jackson et al. (1988) also showed that several riverine fishes were not able to adapt to the new conditions and disappeared from the reservoir. In Amazonian reservoirs, the number of fish species was reduced as compared to preimpoundment faunas: 55 reservoir species vs 214 riverine species in Curuá-Una Reservoir, 127 vs 141 in Tucuruí Reservoir, and 43 vs 126 in Petit Saut Reservoir (Table 6). The number of pre-impoundment fish species for Jamari (122) and Tocantins (141) rivers was probably underestimated by gill net sampling because Santos et al. (1984) indicate for Tocantins River a total 
number of 300 species collected by diverse gears. The dominance of only two or three fish species in reservoir faunas was reflected in a reduced species diversity and evenness in Brokopondo, Tucuruí and Samuel reservoirs as compared to pre-impoundment river faunas (Table 6).

Fish communities of reservoirs are the result of a restructuring of local riverine communities (Agostinho et al., 1999). The zooplanktivorous catfish Hypophthalmus did not occur in the middle Suriname River before impoundment and its absence from Brokopondo Reservoir may well have allowed for the success of $B$. melanurus in open water. In Curuá-Una Reservoir, Bryconops was also abundant in the absence of $\mathrm{Hy}$ pophthalmus, whereas in Petit Saut Reservoir the zooplanktivorous niche was occupied by Triportheus (Table 6). Piranhas (Serrasalmus spp) and peacock cichlids (Cichla spp) were highly successful in Amazonian reservoirs (including Brokopondo), but they did not occur in Sinnamary River and consequently they were also absent from Petit Saut Reservoir (Table 6). Other predatory fishes that were successful in Amazonian reservoirs include Acestrorhynchus, Hoplias, Plagioscion, Boulengerella and Hydrolycus (Table 6; the latter two genera absent from Suriname River and Brokopondo Reservoir).

Large migratory catfishes of Suriname River ( $B$. filamentosum, $H$. platyrhynchos and $P$. fasciatum) were not collected in Brokopondo Reservoir in 1978 and 2002-2005. Many large-sized migratory catfishes are mainstays of Neotropical subsistence and commercial river fisheries, but they are vulnerable to damming because of their wide-ranging habits (Barthem et al., 1991; Araujo-Lima et al., 1995; Agostinho et al., 1999; Carolsfeld et al., 2003). However, different species react to damming differently and some may be able to survive in the smaller sections of river that are available to them after a dam is erected. In Tucuruí (Ribeiro et al., 1995) and Itaipu (Agostinho et al., 1999) reservoirs, large migratory catfishes - after initial increase based on populations upstream of the reservoir - became rare. However, Pterodoras granulosus was able to extend its distribution from the Lower and Middle Paraná to Upper Paraná and Itaipu Reservoir after the reservoir inundated the natural barrier of Sete Quedas Falls (Agostinho et al., 1999).

Potamodromous detritivorous characoids were more successful in Amazonian reservoirs than piscivorous migratory catfishes. In Brokopondo Reservoir, P. rubrotaeniatus was collected in both 1978 (Richter \& Nijssen, 1980) and 2002-2005 (present study). In Guri (Novoa et al., 1991) and Tucuruí (Ribeiro et al., 1995) reservoirs, the decomposing inundated vegetation became a major feeding habitat for Semaprochilodus and Prochilodus and important fisheries targeted these species both in the reservoir and during their upriver spawning runs. Nijssen (1969) observed a shoal of Prochilodus leaving Brokopondo Reservoir moving up the Suriname River (where it is important in subsistence fisheries). However, downstream of the dam Prochilodus virtually disappeared from Tocantins (Ribeiro et al., 1995) and Suriname (E. Fonkel, pers. comm.) rivers.

Rheophylic fishes adapted to fast currents in rapids did not survive in non-flowing water of Brokopondo Reservoir (present study) and African reservoirs (Jackson et al., 1988). Rapid-dwelling fishes occurred in Sinnamary River (Horeau et al., 1998) but were not collected in Petit Saut Reservoir (BdM, unpublished data). Fishes from other specific riverine habitats like sandy beaches, submerged leaf litter, woody debris and low-order headwater streams would probably not survive impoundment because their habitat is drowned in the reservoir. Examples of Suriname River habitat specialists that did not survive in Brokopondo Reservoir include Gymnorhamphichthys (burrows in sandy bottoms), small-sized characoids, catfishes and cichlids from leaf litter, and Ancistrus from woody debris. A case in point is the miniature catfish Lithoxus pallidimaculatus (36-46 $\mathrm{mm} \mathrm{SL}$ ), endemic to the Suriname River basin and known only from four specimens collected in a first-order tributary of Sara Creek (Boeseman, 1982), which may now be at risk of extinction or already extinct after inundation of its collection locality.

Brokopondo Reservoir, like the first great African impoundments, was a genuine novelty and there was no basis in experience on which to predict its consequences (Leentvaar, 1973). Subsequent Amazonian reservoirs had similar short-term environmental (Fearnside, 2001) and social (Fearnside, 1999) impacts. The long-term impact of Brokopondo Dam on the preimpoundment riverine fish fauna was a drastic decrease in number of species, species diversity and evenness. Forty years after closure of the dam, some mammals of the rainforest were still negatively affected by the reservoir as revealed by the drowning of peccaries and other species that try to swim across the large reservoir (F. van Troon, pers. communication). Commercial fisheries, often a positive effect of tropical reservoirs (Jackson, 1975), never developed on Brokopondo Reservoir (Kapetsky, 1978) probably because the most abundant largesized species, S. rhombeus, destroys gill nets and is not an appreciated food fish in Suriname. High mercury levels in predatory fishes from Brokopondo Reservoir (Mol et al., 2001), associated with a recent (1990s) boom in small-scale gold mining, pose a serious health problem to Maroon people in the reservoir area (e.g. Brownsweg) and affect sport fishing on peacock cichlid Cichla. Migratory fishes can transport bioaccumulated mercury from the reservoir to villages along the upper Suriname River.

We are aware that hydropower can be a solution for the energy demand of future projects in Suriname (e.g. Kabalebo River project) and Amazonia, but a small catchment and flat topography results in large reservoirs that generate little power (low MW/km²) such as Balbina (Brazil) and Brokopondo reservoirs. Reservoir construction is never warranted without prior assessment of alternatives based on scientific knowledge (Ackerman et al., 1973). Adverse effects in the reservoir area, downstream of the dam and in upper parts of the watershed should be prevented, mitigated or compensated. Since the construction of Brokopondo Reservoir and the large African reservoirs in the 1950s and 1960s, sustainability of economic development has become top priority in the policy of the World Bank (Goodland, 1990) and, consequently, the World Bank refused to finance construction of the Tucuruí Dam because environmental problems were not adequately addressed (Fearnside, 2001). A rational approach to long-term sustainable use of natural resources in a watershed should include ecological zoning and integration of all ecological 
Table 6. Relative abundance in numbers (N, \%) and biomass (M, \%) of dominant reservoir fishes in pre- and post-impoundment studies of Amazonian reservoirs; $\mathrm{nc}=$ not collected during study; $\mathrm{np}=$ not present in pre-impoundment riverine fauna. Source of data: Brokopondo Reservoir (present study), Guri Reservoir (Alvarez et al., 1986; Novoa et al., 1991), Curuá-Una Reservoir (Vieira, 1982), Tucuruí Reservoir (Leite, 1993), Samuel Reservoir (Santos, 1995), Petit Saut Reservoir (Tito de Morais \& Lauzanne, 1994; Mérona et al., 2003). No data are available of the fish fauna in the Guri Reservoir area before closure of the $\mathrm{dam}^{1}$. No pre-impoundment data for Curua-Una dam are available; presented are data of the fish fauna of the Curua-Una River up- and downstream of dam ${ }^{2}$. Later in time (1982-1983), Ferreira (1984) found Hemiodus spp together with Auchenipterus and Serrasalmus dominant in number of specimens in Curua-Una Reservoir ${ }^{3}$. Piranha species in Tucuruí Reservoir included the redbelly piranha Pygocentrus nattereri ${ }^{4}$. Santos et al. (1984) indicate a total number of 300 species collected by diverse gears in Tocantins River5.

\begin{tabular}{|c|c|c|c|c|c|c|c|c|c|c|c|c|c|}
\hline \multicolumn{14}{|l|}{ Reservoir characteristics } \\
\hline Reservoir & & Guri & \multicolumn{2}{|c|}{ Curuá-Una } & \multicolumn{2}{|c|}{ Tucuruí } & \multicolumn{2}{|c|}{ Samuel } & \multicolumn{2}{|c|}{ Petit-Saut } \\
\hline Country & \multicolumn{2}{|c|}{ Suriname } & & & Venezuela & \multicolumn{2}{|c|}{ Brazil } & \multicolumn{2}{|c|}{ Brazil } & \multicolumn{2}{|c|}{ Brazil } & \multicolumn{2}{|c|}{ French Guiana } \\
\hline River & \multicolumn{4}{|c|}{ Suriname } & Caroni & \multicolumn{2}{|c|}{ Curuá-Una } & \multicolumn{2}{|c|}{ Tocantins } & \multicolumn{2}{|c|}{ Jamari } & \multicolumn{2}{|c|}{ Sinnamary } \\
\hline Year of closure of dam & \multicolumn{4}{|c|}{1964} & 1968 & \multicolumn{2}{|c|}{1977} & \multicolumn{2}{|c|}{1984} & \multicolumn{2}{|c|}{1988} & \multicolumn{2}{|c|}{1994} \\
\hline Surface area $\left(\mathrm{km}^{2}\right)$ & \multicolumn{4}{|c|}{1560} & 4300 & \multicolumn{2}{|c|}{87} & \multicolumn{2}{|c|}{2430} & \multicolumn{2}{|c|}{580} & \multicolumn{2}{|c|}{350} \\
\hline Residence time (months) & \multicolumn{4}{|c|}{26} & $?$ & & & & & & & ( & \\
\hline $\begin{array}{l}\text { Reservoir age in post- } \\
\text { impoundment study (years) }\end{array}$ & & & 10 & & 16 & & & & & & & 0 & 7 \\
\hline Fish community structure & & & & & & & & & & & & & \\
\hline Taxon & Mpre & Npre & Mpost & Npost & Mpost $^{1}$ & Nriv $^{2}$ & Npost & Npre & Npost & Npre & Npost & Mpre & Mpost \\
\hline Bryconops spp. & 1.5 & 3.6 & 5.3 & 36.6 & 0.0 & 32.4 & 23.3 & 0.0 & 0.5 & 0.0 & 0.0 & 5.6 & 4.8 \\
\hline Triportheus spp. & 0.4 & 0.1 & 0.0 & 0.0 & $\mathrm{nc}$ & 0.3 & 0.0 & 5.8 & 5.1 & 0.0 & 0.0 & 9.1 & 39.6 \\
\hline Hemiodus spp. & 5.0 & 4.0 & 6.1 & 18.9 & 0.0 & 5.4 & $0.1^{3}$ & 13.3 & 8.2 & 0.0 & 1.0 & 4.6 & 1.6 \\
\hline Prochilodus spp. & 0.13 & 0.04 & 1.35 & 0.11 & 63.3 & $\mathrm{nc}$ & & 0.7 & 1.6 & 6.4 & 0.0 & $\mathrm{np}$ & \\
\hline Acestrorhynchus spp. & 3.4 & 2.3 & 2.6 & 1.6 & 0.0 & 7.6 & 34.4 & 0.4 & 3.1 & 0.0 & 4.0 & 13.0 & 8.6 \\
\hline Boulengerella spp. & $\mathrm{np}$ & & & & $\mathrm{nc}$ & 4.4 & 4.9 & 4.0 & 3.0 & 1.9 & 0.0 & $\mathrm{np}$ & \\
\hline Charax spp. & 0.6 & 0.9 & 0.0 & 0.1 & 0.0 & 1.7 & 6.3 & 0.0 & 0.0 & $\mathrm{nc}$ & & 0.4 & 4.8 \\
\hline Hydrolycus spp. & $\mathrm{np}$ & & & & 10.3 & 0.5 & 0.0 & 2.5 & 5.1 & 6.3 & 0.0 & $\mathrm{np}$ & \\
\hline Hoplias spp. & 2.6 & 1.1 & 0.9 & 1.0 & 3.4 & 0.3 & 0.3 & 0.0 & 0.0 & 2.5 & 0.0 & 26.9 & 5.0 \\
\hline Serrasalmus spp. & 1.4 & 0.4 & 67.7 & 11.8 & 2.4 & 3.9 & 11.6 & 1.1 & $29.9^{4}$ & 0.0 & 54.3 & $\mathrm{np}$ & \\
\hline Auchenipterus spp. & 0.0 & 0.1 & 0.0 & 0.0 & 0.0 & 6.8 & 5.5 & 10.6 & 1.7 & 0.0 & 0.0 & 2.8 & 4.6 \\
\hline Hypophthalmus spp. & $\mathrm{np}$ & & & & $\mathrm{nc}$ & $\mathrm{nc}$ & & 0.0 & 0.3 & 0.0 & 16.0 & $\mathrm{np}$ & \\
\hline Trachelyopterus galeatus & 0.3 & 1.0 & 0.0 & 0.0 & 0.0 & 0.3 & 1.5 & 0.0 & 4.4 & 0.0 & 2.0 & 0.3 & 11.9 \\
\hline Cichla spp. & 1.6 & 1.5 & 2.8 & 3.2 & 5.7 & 0.2 & 1.9 & 0.5 & 5.1 & 0.0 & 9.0 & $\mathrm{np}$ & \\
\hline Geophagus spp. & 4.9 & 5.6 & 2.8 & 7.1 & 0.2 & 0.1 & 1.3 & 1.1 & 0.7 & 4.1 & 0.0 & 0.1 & 0.0 \\
\hline Plagioscion spp. & 0.1 & 0.1 & 1.1 & 0.1 & 10.8 & 0.0 & 0.0 & 0.6 & 1.0 & 0.3 & 0.0 & 0.0 & 0.0 \\
\hline Total & 21.9 & 20.7 & 90.6 & 80.5 & 96.1 & 63.9 & 91.1 & 40.6 & 69.7 & 21.5 & 86.3 & 62.8 & 80.9 \\
\hline Number of species $S$ & 172 & & 41 & & 58 & 214 & 55 & $141^{6}$ & 127 & 122 & & 126 & 43 \\
\hline Species diversity $H$ & 3.76 & 4.11 & 1.53 & 2.17 & & & & 4.7 & 3.4 & 3.09 & 1.61 & & 2.9 \\
\hline Evenness $J$ & 0.74 & 0.80 & 0.42 & 0.60 & & & & 0.78 & 0.67 & 0.81 & 0.55 & & 0.7 \\
\hline
\end{tabular}

and socio-economic implications into an overall River Basin Plan (Ribeiro et al., 1995).

\section{Acknowledgments}

We thank two anonymous reviewers for their comments on an earlier draft of the paper. We thank Philippe Cerdan, Anil Gangadin, Stanley Ramanand, Ashwin Sahdew, Rawin Jairam, Régis Vigouroux and others for help in the field. We thank Martien van Oijen (Naturalis Museum, Leiden) for permission to study the 1963-1964 collection of fishes from the Suriname River of M. Boeseman. This study was funded by Electricité de France.

\section{Literature Cited}

Ackermann, W. C., G. F. White \& E. B. Worthington (Eds.). 1973. Man-Made Lakes: Their Problems and Environmental Effects. Washington D.C., American Geophysical Union, 847p.

Agostinho, A. A., L. E. Miranda, L. M. Bini, L. C. Gomes, S. M. Thomaz \& H. I. Suzuki. 1999. Patterns of colonization in neotropical reservoirs and prognoses on aging. Pp. 227-265. In: Tundisi, J. G. \& M. Straskraba (Eds.). Theoretical Reservoir
Ecology and its Applications. Leiden, the Netherlands, Brazilian Academy of Sciences \& Backhuys Publishers, 583p.

Alvarez, E., L. Balbas, I. Massa \& J. Pacheco. 1986. Aspectos ecologicos del embalse Guri. Interciencia, 11: 325-333.

Amatali, M. A. 1993. Climate and surface water hydrology. Pp. 2951. In: P.E. Ouboter (Ed.). The Freshwater Ecosystems of Suriname. Dordrecht, the Netherlands, Kluwer, 313p.

Araujo-Lima, C. A. R. M., A. A. Agostinho \& N. N. Fabre. 1995. Trophic aspects of fish communities in Brazilian rivers and reservoirs. Pp. 105-136. In: J. G. Tundisi, C. E. M. Bicudo \& T. Matsumura Tundisi (Eds.). Limnology in Brazil. Rio de Janeiro, Brazilian Academy of Sciences, 376p.

Aula, I., H. Braunschweiler, T. Leino, I. Malin, P. Porvari, T. Hatanaka, M. Lodenius \& A. Juras. 1994. Levels of mercury in the Tucuruí Reservoir and its surrounding area in Pará, Brazil. Pp. 21-40. In: Watras, C. J. \& J. W. Huckabee (Eds). Mercury Pollution: Integration and Synthesis. Boca Raton, Lewis Publishers.

Balon, E. K. 1974. Fish production of a tropical ecosystem. Pp. 264277. In: E. K. Balon \& A. G. Coche (Eds.). Lake Kariba: a ManMade Ecosystem in Central Africa. The Hague, Junk, 767p.

Barthem, R. B., M. C. L. B. Ribeiro \& M. Petrere. 1991. Life strategies of some long- distance migratory catfish in relation to hydroelectric dams in the Amazon basin. Biological Conservation, 55: 339-345. 
Baxter, R.M. 1977. Environmental effects of dams and impoundments. Annual Review in Ecology and Systematics, 8: 255-283.

Boeseman, M. 1964. Ichthyological and other zoological observations (December 1963 - March 1964). Progress Reports Biological Brokopondo Research Project, 1: 11-15, 32-35, 53-55.

Boeseman, M. 1968. The genus Hypostomus Lacépède, 1803, and its Surinam representatives (Siluriformes, Loricariidae). Zoologische Verhandelingen Leiden, 99: 1-89.

Boeseman, M. 1971. The 'comb-toothed' Loricariinae of Surinam, with reflections on the phylogenetic tendencies within the family Loricariidae (Siluriformes, Siluroidei). Zoologische Verhandelingen Leiden, 116: 1-56.

Boeseman, M. 1982. The South American mailed catfish genus Lithoxus Eigenmann, 1910, with the description of three new species from Surinam and French Guyana and records of the related species (Siluriformes, Loricariidae). Proceedings Koninklijke Nederlandse Academie Wetenschappen, C85:41-58.

Burgess, W. E. 1989. An Atlas of Freshwater and Marine Catfishes. Neptune City, New Jersey, T.F.H. Publications, 784p.

Carolsfeld, J., B. Harvey, C. Ross \& A. Baer (Eds.). 2003. Migratory Fishes of South America: Biology, Fisheries and Conservation Status. Ottawa, International Development Research Centre \& the World Bank, 372p.

Carvalho, F. M. 1980. Alimentação do mapará (Hypophthalmus edentatus Spix, 1829) do lago Castanho, Amazonas (Siluriformes, Hypophthalmidae). Acta Amazonica, 10: 545-555.

Clarke, D. \& J. Rhodes. 2006. Plant diversity of the Central Suriname Nature Reserve: implications for conservation and biogeography. Pp. 47-55. In: L. Alonso \& H.J. Berrenstein (Eds.). A Rapid Biological Assessment of the Aquatic Ecosystems of the Coppename River, Central Suriname Nature Reserve, Suriname. RAP Bulletin of Biological Assessment 39. Washington D.C., Conservation International.

Densen, W. L. T. \& M. J. Morris. 1999. Fish and Fisheries of Lakes and Reservoirs in Southeast Asia and Africa. Otley, UK, Westbury, 432p.

Donselaar, J. van. 1968. Water and marsh plants in the artificial Brokopondo Lake (Surinam, S. America) during the first three years of its existence. Acta Botanica Neerlandica, 17: 183-196.

Donselaar, J. van. 1989. The vegetation in the Brokopondo-Lake basin (Surinam) before, during, and after the inundation, 19641972. Brokopondo Research Report, 3: 1-45.

Eigenmann, C. H. 1912. The freshwater fishes of British Guiana, including a study of the ecological groupings of species and the relation of the fauna of the plateau to that of the lowlands. Memoirs of the Carnegie Museum, 5: 1-578.

Fearnside, P. M. 1999. Social impacts of Brazil's Tucuruí Dam. Environmental Management, 24: 483-495.

Fearnside, P. M. 2001. Environmental impacts of Brazil's Tucuruí Dam: unlearned lessons for hydroelectric development in Amazonia. Environmental Management, 27: 377-396.

Fernando, C. H. 1994. Zooplankton, fish and fisheries in tropical freshwaters. Hydrobiologia, 272: 105-123.

Fernando, C. H. \& J. Holèik. 1982. The nature of fish communities: a factor influencing the fishery potential and yields of tropical lakes and reservoirs. Hydrobiologia, 97: 127-140.

Ferreira, E. J. 1984. A ictiofauna da represa hidrelétrica de CuruáUna, Santarém, Pará. II. Alimentação e hábitos alimentares das principais espécies. Amazoniana, 9: 1-16.

Géry, J. 1972. Poissons characoïdes des Guyanes. I. Généralités. II. Famille des Serrasalmidae. Zoologische Verhandelingen Leiden, 122: 3-266.

Géry, J. 1977. Characoids of the World. Neptune City, USA, TFH Publications, 672p.
Goodland, R. J. A. 1979. Environmental optimization in hydrodevelopment of tropical forest regions. Pp. 10-20. In: R.S. Panday (Ed.). Man-made Lakes and Human Health. Paramaribo, Suriname, Proceedings of the Symposium on Manmade Lakes and Human Health, 73p.

Goodland, R. J. A. 1990. The World Bank's new policy on the environmental aspects of dam and reservoir projects. In: Environmental Aspects of Amazonian Hydroprojects. Brasilia, ELETRONORTE, $31 \mathrm{p}$.

Heide, J. van der. 1982. Lake Brokopondo: Filling Phase Limnology of a Man-Made Lake in the Humid Tropics. Alblasserdam, the Netherlands, Kanters, 427p.

Horeau, V., P. Cerdan, A. Champeau \& S. Richard. 1998. Importance of aquatic invertebrates in the diet of rapids-dwelling fish in the River Sinnamary, French Guiana. Journal of Tropical Ecology, 14: 851-864.

Hydraulic Research Division Suriname. 1970. Quality and Availability of River Water in the Coastal Area of Surinam. 9. Hydrological Data Lower Suriname River. Paramaribo, Suriname, Hydraulic Research Division (Waterloopkundige Afdeling WLA), Ministry of Public Works, 175p.

Jackson, P. B. N. 1975. Fish. Pp. 259-275. In: N.F. Stanley \& M.P. Alpers (Eds.). Man-Made Lakes and Human Health. London, Academic Press, 495p.

Jackson, P. B. N., B. E. Marshall \& D. Paugy. 1988. Fish communities in man-made lakes. Pp. 325-350. In: C. Leveque, M.N. Bruton \& G.W. Ssentogo (Eds.). Biology and Ecology of African Freshwater Fishes. Paris, ORSTOM, 508p.

Kapetsky, J. M. 1978. The Brokopondo Reservoir Fishery Yield, Fishery Research and Fishery Development. Rome, FAO, 81p.

Keith, P., P. Y. Le Bail \& P. Planquette. 2000. Atlas des Poissons d'Eau Douce de Guyane. Tome 2 - fascicule I. Batrachoidiformes, Mugiliformes, Beloniformes, Cyprinodontiformes, Synbranchiformes, Perciformes, Pleuronectiformes, Tetraodontiformes. Paris, Museum National d'Histoire Naturelle, 286p.

Köppen, W. 1936. Das geographische System der Klimate. Handbuch der Klimatologie. Vol. I, C. Berlin, Bornträger, 44p.

Krebs, C. J. 1989. Ecological Methodology. New York, Harper Collins, 654p.

Kullander, S. O. \& H. Nijssen. 1989. The Cichlids of Surinam, Teleostei: Labroidei. Leiden, E.J. Brill, 256p.

Le Bail, P. Y., P. Keith \& P. Planquette. 2000. Atlas des Poissons d'Eau Douce de Guyane. Tome 2 - fascicule II. Siluriformes. Paris, Museum National d'Histoire Naturelle, 307p.

Leentvaar, P. 1973. Lake Brokopondo. Pp. 186-196. In: W.C. Ackermann, G. F. White \& E. B. Worthington (Eds.). ManMade Lakes: Their Problems and Environmental Effects. Washington D.C., American Geophysical Union, 847p.

Leite, R. 1993. Efeitos da usina hidroelétrica de Tucuruí sobre a composição da ictiofauna das pescarias experimentais de malhadeiras realizadas no baixo rio Tocantins (Pará). Unpublished MSc. Dissertation, INPA/FUA, Manaus, 73p.

Lowe-McConnell, R. H. 1973. Reservoirs in relation to manfisheries. Pp. 641-654. In: W. C. Ackermann, G. F. White \& E. B. Worthington (Eds.). Man-Made Lakes: their Problems and Environmental effects. Washington D.C., American Geophysical Union, 847p.

Matthews, W. J. 1998. Patterns in Freshwater Fish Ecology. London, Chapman \& Hall, 756p.

Mees, G. F. 1967. Ichthyological and other zoological observations (March 1965-March 1966). Progress Reports Biological Brokopondo Research Project, 3: 161-171.

Mees, G. F. 1974. The Auchenipteridae and Pimelodidae of Suriname 
(Pisces, Nematognathi). Zoologische Verhandelingen Leiden, 132: 1-256.

Mérona, B. de. 2002. Dynamique des peuplements de poissons dans le réservoir de Petit-Saut (fleuve Sinnamary, Guyane française). Bull. Fr. Pêche Piscic., 364: 10-18.

Mérona, B. de \& R. Vigouroux. 2005. Alterations of fish diversity downstream from Petit-Saut Dam in French Guiana. Implication of ecological strategies of fish species. Hydrobiologia, 551: 33-47.

Mérona, B. de, G. M. dos Santos \& R.G. de Almeida. 2001. Short term effects of Tucuruí Dam (Amazonia, Brazil) on the trophic organization of fish communities. Environmental Biology of Fishes, 60: 375-392.

Mérona, B. de, R. Vigouroux \& V. Horeau. 2003. Changing in food resources and their utilization by fish assemblages in a large tropical reservoir in South America (Petit-Saut Dam, French Guiana). Acta Oecologia, 24: 147-156.

Mol, J. H., J. S. Ramlal, C. Lietar \& M. Verloo. 2001. Mercury contamination in freshwater, estuarine and marine fishes in relation to small-scale gold mining in Suriname, South America. Environmental Research, 86: 183-197.

Mol, J. H., P. W. Willink, B. Chernoff \& M. Cooperman. 2006. Fishes of the Coppename River, Central Suriname Nature Reserve, Suriname. Pp. 67-79. In: L. Alonso \& H. J. Berrenstein (Eds.). A Rapid Biological Assessment of the Aquatic Ecosystems of the Coppename River Basin, Suriname. RAP Bulletin of Biological Assessment 39. Washington D.C., Conservation International.

Moyle, P. B. \& R. A. Leidy. 1992. Loss of aquatic ecosystems: evidence from fish faunas. Pp. 127-169. In: P.L. Fielder \& S.K. Jain (Eds.). Conservation Biology: the Theory and Practice of Nature Conservation, Preservation and Management. New York, Chapman \& Hall.

Nijssen, H. 1967. Ichthyological observations (May-December 1966). Progress Reports Biological Brokopondo Research Project, 3: 172-180.

Nijssen, H. 1969. Ichthyological observations (January - June 1967). Final remarks and tentative list of fish species. Progress Reports Biological Brokopondo Research Project, 4: 234-246.

Nijssen, H. 1970. Revision of the Surinam catfishes of the genus Corydoras Lacépède, 1803 (Pisces, Siluriformes, Callichthyidae). Beaufortia, 18: 1-75.

Novoa, D., J. Koonce, F. Ramos \& A. Locci. 1991. Evaluacion del potencial pesquero del lago de Guri (Venezuela). Estrategias de ordenamiento pesquero. Pp. 112-146. In: I. Vila (Ed.). Segundo Taller Internacional sobre Ecologia y Manejo de Peces en Lagos y Embalses. FAO, Oficina Regional para America Latina y el Caribe, COPESCAL Documento Tecnico.

Ouboter, P. E. \& J. H. Mol. 1993. The fish fauna of Suriname. Pp. 133-154. In: P.E. Ouboter (Ed.). The Freshwater Ecosystems of Suriname. Dordrecht, the Netherlands, Kluwer, 313p.

Panday-Verheuvel, M. P. 1983. Factors influencing water quality and life in the Suriname River. Pp. 473-501. In: D. Bekker \& H. Ehrenburg (Eds.). Future of Roads and Rivers in Suriname and Neighbouring Countries. Paramaribo, Proceedings FURORIS congress Paramaribo, 2-7 December 1982, 536p.

Planquette, P., P. Keith \& P. Y. Le Bail. 1996. Atlas des Poissons d'Eau Douce de Guyane (Tome 1). Paris, Museum National d'Histoire Naturelle, 429p.
Ponton, D. \& S. Mérigoux. 2000. Comparative morphology and diet of young cichlids in the dammed River Sinnamary (French Guiana, South America. Journal of Fish Biology, 56: 87-102.

Ponton, D., S. Mérigoux \& G. H. Copp. 2000. Impact of dams in the neotropics: what can be learned from young-of-the-year fish assemblages in tributaries of the River Sinnamary (French Guiana, South America)? Aquatic Conservation: Marine and Freshwater Ecosystems, 10: 25-51.

Reis, R. E., S. O. Kullander \& C. J. Ferraris (Eds.). 2003. Checklist of the Freshwater Fishes of South and Central America. Porto Alegre, Edipucrs, 724p.

Ribeiro, M. C. L. B., M. Petrere \& A.A. Juras. 1995. Ecological integrity and fisheries ecology of the Araguaia-Tocantins River Basin. Regulated Rivers: Research \& Management, 11: 325-350.

Richter, C. J. J. \& H. Nijssen. 1980. Notes on the fishery potential and fish fauna of the Brokopondo Reservoir (Surinam). Fisheries Management, 11: 119-130.

Ringma, S. H. 1953. Combinatieplan Suriname rivier (Brokopondo plan). Hydrologische Nota no. 5. Eindverslag Afvoerjaar 1952. Paramaribo, Stichting Planbureau Suriname, 62p.

Santos, G. M. dos. 1995. Impactos da hidrelétrica Samuel sobre as comunidades de peixes do Rio Jamari (Rondônia, Brasil). Acta Amazonica, 25: 247-280.

Santos, G. M. dos, M. Jégu \& B. de Merona. 1984. Catálogo de peixes comerciais do baixo rio Tocantins. Brasilia, Eletronorte/ INPA, 83p.

Saul, W. G. 1975. An ecological study of fishes at a site in upper Amazonian Ecuador. Proceedings of the Academy of Natural Sciences of Philadelphia, 127: 93-134.

Sioli, H. 1950. Das Wasser im Amazonasgebiet. Forschung und Fortschritt, 26: 274-280.

Tito de Morais, L. \& L. Lauzanne. 1994. Zonation longitudinale des peuplements ichthyques avant mise en eau de la retenue de Petit-Saut (Guyane francaise). Revue d'Hydrobiologie Tropicale, 27: 467-483.

Tundisi, J. G., T. Matsumura-Tundisi \& M. C. Calijuri. 1993. Limnology and management of reservoirs in Brazil. Pp. 25-55. In: M. Straškraba, J. G. Tundisi \& A. Duncan (Eds.). Comparative Reservoir Limnology and Water Quality Management. Dordrecht, the Netherlands, Kluwer, 291p.

Vieira, I. 1982. Aspectos sinecológicos da ictiofauna de Curuá-Una, represa hidroelétrica da Amazônia brasileira. Unpublished Ph.D. Dissertation, Universidade Federal Juiz de Fora, Juiz de fora, Minas Gerais, 107p.

Ward, J. V. \& J. A. Stanford. 1983. The serial discontinuity concept in lotic ecosystems. Pp.29-42. In: T.D. Fontaine \& S.M. Bartell (Eds.). Dynamics in Lotic Ecosystems. Ann Arbor, MI, Ann Arbor Scientific, 494p.

Ward, J. V. \& J. A. Stanford. 1995. The serial discontinuity concept: extending the model to floodplain rivers. Regulated Rivers: Research \& Management, 10: 159-168.

Zaret, T. M. 1980. Life-history and growth relationships of Cichla ocellaris, a predatory South American cichlid. Biotropica, 12: 144-157.

Submitted September 2006 Accepted August 2007 
Appendix 1. Fish community structure of Suriname River in future Brokopondo Reservoir area (i.e. upstream of the first rapids at Phedra; $135 \mathrm{~km}$ from the estuary) in 1963-1964 (collection of M. Boeseman in Naturalis Museum, Leiden, The Netherlands) and Brokopondo Reservoir in 1966-1967 (presence/absence only; Nijssen, 1967, 1969; Richter \& Nijssen, 1980), 1978 (Kapetsky, 1978; Richter \& Nijssen, 1980) and 2002-2005 (present study) in proportion of number of specimens (N) and wet mass (M). Number of samples in parentheses. Community structure of shore habitat in 1978 is based on one sample (Kapetsky, 1978) for number of specimens, but three samples for wet mass ${ }^{1}$. Also given are number of species, Shannon-Wiener index of species diversity $(H)$ and evenness $(J)$. Fishes endemic to the Suriname River basin are denoted with an asterisk. The fish species H. aimara, $S$. eigenmanni, P. squamosissimus and P. surinamensis were caught in Brokopondo Reservoir in 2000 by Mol et al. (2001) ${ }^{2}$. The large catfish Brachyplatystoma filamentosum was photographed by Boeseman at Brokopondo in February 1964 (see Mees, 1974, Plate 15); the specimen is identified as B. vaillantii in Mees (1974), but taking into account its large size (170 cm TL) this should be $B$. filamentosum; here we use a conservative estimate of its weight (30 kg; see length-weight relationship at http:// www.fishbase.org W $\left.=0.0102 * \mathrm{TL}^{3}\right)^{3}$. Richter \& Nijssen (1980) probably misidentified Pimelodus blochii as Pimelodus albofasciatus Mees, $1974^{4}$, Crenicichla multispinosa as Crenicichla lugubris Heckel, 1840 ${ }^{5}$, and Guianacara owroewefi as Guianacara geayi (Pellegrin, 1902) ${ }^{6}$. Tarpon M. atlanticus is a catadromous species which was observed in the Suriname River as far upstream as Berg en Dal (km 165) (Mees, 1967)7. The guppy M. bifurca was observed in Suriname River (Boeseman, 1964) and Brokopondo Reservoir (Nijssen, 1967) ${ }^{8}$. The biomass of the shore community in 1978 is expressed in kg per ha9.

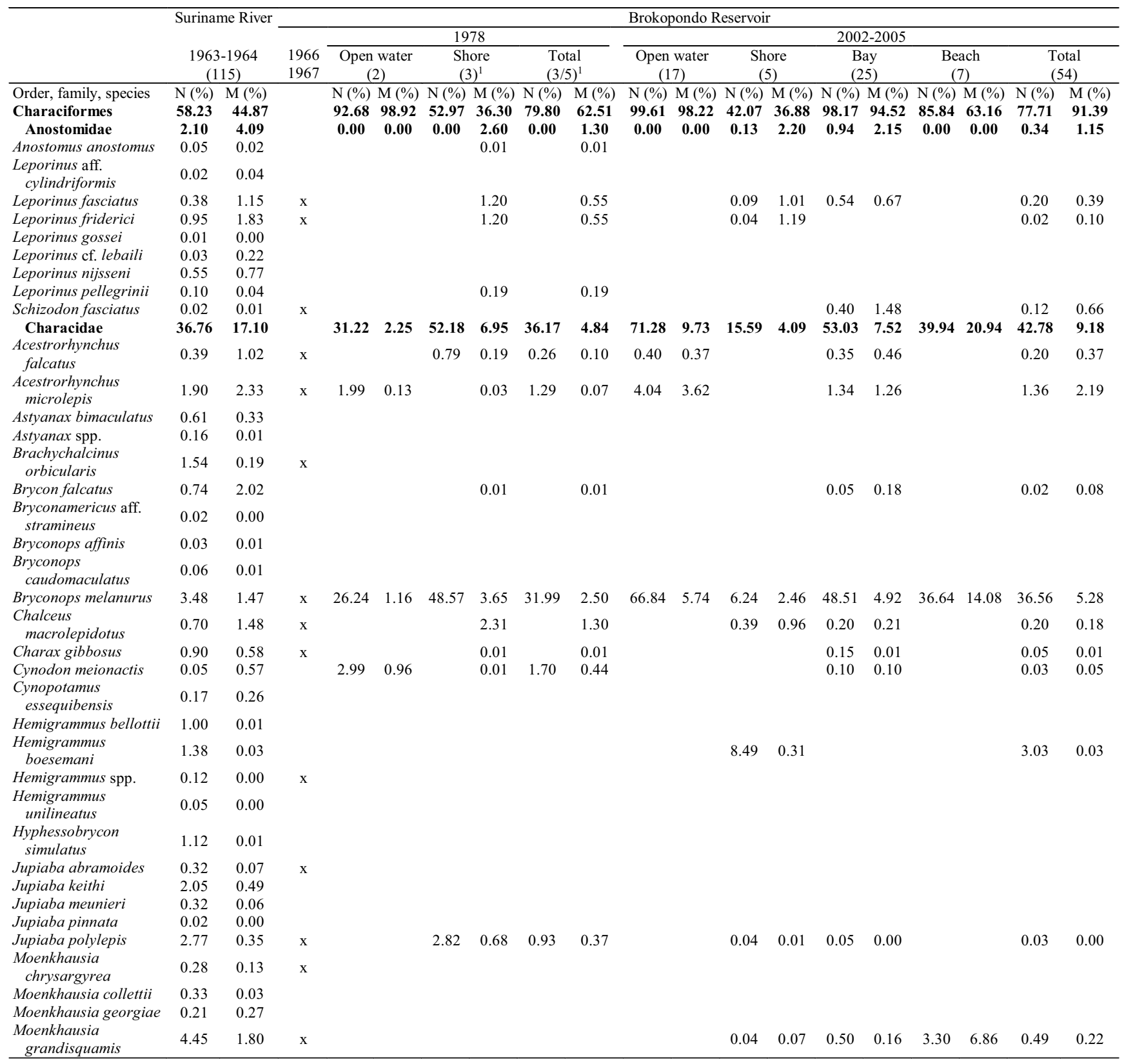


Appendix 1. Cont.

\begin{tabular}{|c|c|c|c|c|c|c|c|c|c|c|c|c|c|c|c|c|c|c|c|}
\hline \multirow[b]{4}{*}{$\begin{array}{l}\text { Moenkhausia } \\
\text { hemigrammoides }\end{array}$} & \multirow{3}{*}{\multicolumn{2}{|c|}{$\begin{array}{c}\text { Suriname River } \\
\text { 1963-1964 } \\
(115) \\
\end{array}$}} & \multicolumn{17}{|c|}{ Brokopondo Reservoir } \\
\hline & & & \multirow{3}{*}{$\begin{array}{l}1966 \\
1967 \\
\end{array}$} & \multicolumn{6}{|c|}{1978} & \multicolumn{10}{|c|}{$2002-2005$} \\
\hline & & & & \multicolumn{2}{|c|}{$\begin{array}{c}\text { Open water } \\
\text { (2) }\end{array}$} & \multicolumn{2}{|c|}{$\begin{array}{l}\text { Shore } \\
(3)^{1}\end{array}$} & $\begin{array}{l}\text { Tot } \\
(3 / 5\end{array}$ & & $\begin{array}{r}\text { Open } \\
(1 \\
\end{array}$ & $\begin{array}{l}\text { water } \\
7)\end{array}$ & & $\begin{array}{l}\text { ore } \\
\text { 5) }\end{array}$ & $\begin{array}{l}\mathrm{B} \\
(2 \\
\end{array}$ & $\begin{array}{l}35 y \\
25)\end{array}$ & & 7) & & $\begin{array}{l}\text { otal } \\
54) \\
\end{array}$ \\
\hline & 1.14 & 0.04 & & & & & & & & & & & & & & & & & \\
\hline Moenkhausia lepidura & 0.02 & 0.00 & & & & & & & & & & & & & & & & & \\
\hline Moenkhausia oligolepis & 4.08 & 1.52 & $\mathrm{x}$ & & & & 0.03 & & 0.02 & & & & & & & & & & \\
\hline Moenkhausia spp. & 0.01 & 0.00 & & & & & & & & & & & & & & & & & \\
\hline $\begin{array}{l}\text { Moenkhausia } \\
\text { surinamensis }\end{array}$ & 0.08 & 0.07 & & & & & & & & & & & & & & & & & \\
\hline $\begin{array}{l}\text { Phenacogaster aff. } \\
\text { microstictus }\end{array}$ & 0.58 & 0.01 & & & & & & & & & & & & & & & & & \\
\hline Piabucus dentatus & 0.06 & 0.03 & & & & & & & & & & & & & & & & & \\
\hline Poptella brevispina & 3.26 & 0.96 & $\mathrm{x}$ & & & & 0.03 & & 0.02 & & & 0.35 & 0.27 & 1.04 & 0.12 & & & 0.45 & 0.08 \\
\hline Pristella maxillaris & 0.29 & 0.01 & & & & & & & & & & & & & & & & & \\
\hline $\begin{array}{l}\text { Roeboexodon } \\
\text { guyanensis }\end{array}$ & 0.13 & 0.02 & & & & & & & & & & & & & & & & & \\
\hline Roeboides thurni & 0.04 & 0.02 & $\mathrm{x}$ & & & & & & & & & 0.04 & 0.01 & 0.74 & 0.10 & & & 0.25 & 0.05 \\
\hline $\begin{array}{l}\text { Tetragonopterus } \\
\text { chalceus }\end{array}$ & 1.78 & 0.54 & $\mathrm{x}$ & & & & & & & & & & & & & & & & \\
\hline $\begin{array}{l}\text { Triportheus } \\
\quad \text { brachipomus }\end{array}$ & 0.10 & 0.37 & & & & & & & & & & & & & & & & & \\
\hline Crenuchidae & 0.35 & 0.01 & & 0.00 & 0.00 & 0.00 & 0.00 & 0.00 & 0.00 & 0.00 & 0.00 & 0.00 & 0.00 & 0.00 & 0.00 & 0.00 & 0.00 & 0.00 & 0.00 \\
\hline Characidium zebra & 0.02 & 0.00 & & & & & & & & & & & & & & & & & \\
\hline Crenuchus spilurus & 0.01 & 0.00 & & & & & & & & & & & & & & & & & \\
\hline $\begin{array}{l}\text { Melanocharacidium } \\
\text { dispilomma }\end{array}$ & 0.18 & 0.01 & & & & & & & & & & & & & & & & & \\
\hline $\begin{array}{l}\text { Microcharacidium } \\
\text { eleotrioides }\end{array}$ & 0.14 & 0.00 & & & & & & & & & & & & & & & & & \\
\hline Curimatidae & 6.29 & 9.13 & & 0.00 & $\mathbf{0 . 0 0}$ & $\mathbf{0 . 0 0}$ & 4.24 & 0.00 & 3.81 & 0.07 & 0.23 & $\mathbf{0 . 0 0}$ & $\mathbf{0 . 0 0}$ & 0.79 & 3.51 & $\mathbf{0 . 0 0}$ & 0.00 & 0.26 & 1.67 \\
\hline $\begin{array}{l}\text { Caenotropus } \\
\text { labyrinthicus }\end{array}$ & 0.26 & 0.84 & & & & & & & & & & & & & & & & & \\
\hline Curimata cyprinoides & 2.27 & 6.56 & $\mathrm{x}$ & & & & & & & 0.07 & 0.23 & & & 0.79 & 3.51 & & & 0.26 & 1.67 \\
\hline Curimatella alburna & 0.09 & 0.11 & $\mathrm{x}$ & & & & & & & & & & & & & & & & \\
\hline Cyphocharax helleri & 0.48 & 0.25 & $\mathrm{x}$ & & & & & & & & & & & & & & & & \\
\hline Cyphocharax spilurus & 3.10 & 1.32 & $\mathrm{x}$ & & & & 4.24 & & 3.81 & & & & & & & & & & \\
\hline Steindachnerina varii & 0.09 & 0.04 & & & & & & & & & & & & & & & & & \\
\hline $\begin{array}{l}\text { Erythrinidae } \\
\text { Ervthrinus ervthrinus }\end{array}$ & $\begin{array}{l}\mathbf{1 . 2 4} \\
0.17\end{array}$ & $\begin{array}{l}2.99 \\
0.16\end{array}$ & $\mathrm{x}$ & 0.00 & 0.00 & 0.79 & 16.46 & 0.26 & 10.70 & 0.00 & $\mathbf{0 . 0 0}$ & 2.73 & 10.94 & 0.00 & 0.00 & 0.00 & 0.00 & 0.97 & 0.91 \\
\hline $\begin{array}{l}\text { Hoplerythrinus } \\
\text { unitaeniatus }\end{array}$ & 0.02 & 0.25 & $\mathrm{x}$ & & & & & & & & & & & & & & & & \\
\hline Hoplias aimara & 0.42 & 1.21 & $\mathrm{x}$ & & & & & & & & & & & & & & & $\mathrm{x}^{2}$ & \\
\hline Hoplias malabaricus & 0.63 & 1.37 & $\mathrm{x}$ & & & 0.79 & 16.46 & 0.26 & 10.70 & & & 2.73 & 10.94 & & & & & 0.97 & 0.91 \\
\hline Gasteropelecidae & 4.96 & 0.68 & & 0.00 & $\mathbf{0 . 0 0}$ & 0.00 & 0.00 & 0.00 & 0.00 & $\mathbf{0 . 0 0}$ & 0.00 & 0.00 & $\mathbf{0 . 0 0}$ & $\mathbf{0 . 0 0}$ & $\mathbf{0 . 0 0}$ & $\mathbf{0 . 0 0}$ & $\mathbf{0 . 0 0}$ & 0.00 & $\mathbf{0 . 0 0}$ \\
\hline Carnegiella strigata & 0.02 & 0.00 & $\mathrm{x}$ & & & & & & & & & & & & & & & & \\
\hline $\begin{array}{l}\text { Gasteropelecus } \\
\text { sternicla }\end{array}$ & 4.94 & 0.68 & $\mathrm{x}$ & & & & & & & & & & & & & & & & \\
\hline Hemiodontidae & 4.61 & 5.26 & & 10.63 & 0.90 & 0.00 & 5.61 & 6.91 & 3.27 & 2.58 & 1.04 & 22.71 & 15.88 & 25.64 & 9.22 & 45.59 & 37.96 & 21.17 & 6.71 \\
\hline $\begin{array}{l}\text { Bivibranchia } \\
\text { bimaculata }\end{array}$ & 0.51 & 0.28 & & & & & & & & & & & & & & & & & \\
\hline Bivibranchia simulata & 0.07 & 0.02 & & & & & & & & & & 6.20 & 6.94 & 0.15 & 0.02 & 0.63 & 0.88 & 2.32 & 0.61 \\
\hline Hemiodus argenteus & 0.58 & 0.58 & & & & & & & & 0.26 & 0.05 & 16.29 & 8.37 & 18.66 & 6.09 & 44.65 & 36.06 & 16.08 & 4.20 \\
\hline $\begin{array}{l}\text { Hemiodus } \\
\quad \text { unimaculatus }\end{array}$ & 3.45 & 4.38 & $\mathrm{x}$ & 10.63 & 0.90 & & 5.61 & 6.91 & 3.27 & 2.32 & 0.99 & 0.22 & 0.57 & 6.83 & 3.11 & 0.31 & 1.02 & 2.78 & 1.90 \\
\hline Lebiasinidae & $\mathbf{0 . 3 0}$ & 0.02 & & $\mathbf{0 . 0 0}$ & 0.00 & 0.00 & 0.00 & 0.00 & 0.00 & 0.00 & $\mathbf{0 . 0 0}$ & $\mathbf{0 . 0 0}$ & $\mathbf{0 . 0 0}$ & $\mathbf{0 . 0 0}$ & $\mathbf{0 . 0 0}$ & $\mathbf{0 . 0 0}$ & 0.00 & $\mathbf{0 . 0 0}$ & $\mathbf{0 . 0 0}$ \\
\hline Copella arnoldi & 0.01 & 0.00 & & & & & & & & & & & & & & & & & \\
\hline Copella carsevenennsis & 0.01 & 0.00 & & & & & & & & & & & & & & & & & \\
\hline Nannostomus beckfordi & 0.01 & 0.00 & & & & & & & & & & & & & & & & & \\
\hline $\begin{array}{l}\text { Nannostomus } \\
\text { bifasciatus }\end{array}$ & 0.17 & 0.01 & & & & & & & & & & & & & & & & & \\
\hline Pyrrhulina filamentosa & 0.11 & 0.01 & $\mathrm{x}$ & & & & & & & & & & & & & & & & \\
\hline Prochilodontidae & 0.04 & 0.13 & & 1.33 & 2.31 & 0.00 & 0.40 & 0.83 & 1.28 & 0.13 & 0.91 & $\mathbf{0 . 0 0}$ & 0.00 & 0.25 & 2.12 & $\mathbf{0 . 0 0}$ & $\mathbf{0 . 0 0}$ & 0.11 & 1.35 \\
\hline $\begin{array}{l}\text { Prochilodus } \\
\quad \text { rubrotaeniatus }\end{array}$ & 0.04 & 0.13 & & 1.33 & 2.31 & & 0.40 & 0.83 & 1.28 & 0.13 & 0.91 & & & 0.25 & 2.12 & & & 0.11 & 1.35 \\
\hline Serrasalmidae & 1.58 & 5.46 & & 49.50 & 93.46 & $\mathbf{0 . 0 0}$ & 0.04 & 35.63 & 37.31 & 25.55 & 86.31 & 0.91 & 3.77 & 17.52 & 70.00 & 0.31 & 4.26 & 12.08 & 70.42 \\
\hline Acnodon oligacanthus & 0.55 & 0.42 & & & & & & & & & & & & & & & & & \\
\hline Myleus rhomboidalis & 0.37 & 0.98 & & & & & & & & & & & & & & & & & \\
\hline Myleus ternetzi & 0.14 & 0.45 & & & & & & & & & & & & & & & & & \\
\hline Myloplus rubripinnis & 0.15 & 1.85 & & 1.66 & 2.21 & & 0.04 & 0.94 & 1.02 & 0.07 & 0.35 & & & 0.94 & 5.73 & & & 0.31 & 2.72 \\
\hline $\begin{array}{l}\text { Serrasalmus } \\
\text { eigenmanni }\end{array}$ & $x^{2}$ & & & & & & & & & & & & & & & & & $\mathrm{x}^{2}$ & \\
\hline Serrasalmus rhombeus & 0.36 & 1.40 & $\mathrm{x}$ & 47.84 & 91.25 & & & 34.68 & 36.29 & 25.48 & 85.96 & 0.91 & 3.77 & 17.52 & 64.27 & 0.31 & 4.26 & 11.77 & 67.70 \\
\hline Tometes lebaili & 0.02 & 0.38 & & & & & & & & & & & & & & & & & \\
\hline Gymnotiformes & 2.25 & 2.63 & & 0.00 & 0.00 & 1.63 & 1.01 & 0.54 & 0.55 & 0.00 & 0.00 & 0.22 & 0.41 & 0.00 & 0.00 & $\mathbf{0 . 0 0}$ & 0.00 & 0.08 & $\mathbf{0 . 0 3}$ \\
\hline Apteronotidae & 0.17 & 0.06 & & $\mathbf{0 . 0 0}$ & $\mathbf{0 . 0 0}$ & $\mathbf{0 . 0 0}$ & $\mathbf{0 . 0 0}$ & 0.00 & 0.00 & $\mathbf{0 . 0 0}$ & 0.00 & $\mathbf{0 . 0 0}$ & $\mathbf{0 . 0 0}$ & $\mathbf{0 . 0 0}$ & $\mathbf{0 . 0 0}$ & $\mathbf{0 . 0 0}$ & $\mathbf{0 . 0 0}$ & $\mathbf{0 . 0 0}$ & 0.00 \\
\hline Apteronotus albifrons & 0.17 & 0.06 & & & & & & & & & & & & & & & & & \\
\hline Gymnotidae & 0.31 & 1.35 & & $\mathbf{0 . 0 0}$ & $\mathbf{0 . 0 0}$ & 0.00 & $\mathbf{0 . 0 0}$ & 0.00 & 0.00 & 0.00 & $\mathbf{0 . 0 0}$ & $\mathbf{0 . 0 0}$ & $\mathbf{0 . 0 0}$ & $\mathbf{0 . 0 0}$ & $\mathbf{0 . 0 0}$ & 0.00 & $\mathbf{0 . 0 0}$ & $\mathbf{0 . 0 0}$ & 0.00 \\
\hline $\begin{array}{l}\text { Electrophorus } \\
\text { electricus }\end{array}$ & 0.05 & 0.98 & $\mathrm{x}$ & & & & & & & & & & & & & & & & \\
\hline Gymnotus anguillaris & 0.06 & 0.01 & & & & & & & & & & & & & & & & & \\
\hline Gymnotus carapo & 0.19 & 0.35 & $\mathrm{x}$ & & & & & & & & & & & & & & & & \\
\hline
\end{tabular}


Appendix 1. Cont.

\begin{tabular}{|c|c|c|c|c|c|c|c|c|c|c|c|c|c|c|c|c|c|c|c|}
\hline \multirow[b]{4}{*}{ Hypopomidae } & \multirow{3}{*}{\multicolumn{2}{|c|}{$\begin{array}{c}\text { Suriname River } \\
\text { 1963-1964 } \\
(115)\end{array}$}} & \multicolumn{17}{|c|}{ Brokopondo Reservoir } \\
\hline & & & \multirow{3}{*}{$\begin{array}{l}1966 \\
1967 \\
\end{array}$} & \multicolumn{6}{|c|}{1978} & \multicolumn{10}{|c|}{$2002-2005$} \\
\hline & & & & \multicolumn{2}{|c|}{$\begin{array}{c}\text { Open water } \\
(2)\end{array}$} & \multicolumn{2}{|c|}{$\begin{array}{c}\text { Shore } \\
(3)^{1} \\
\end{array}$} & \multicolumn{2}{|c|}{$\begin{array}{l}\text { Total } \\
(3 / 5)^{1} \\
\end{array}$} & $\begin{array}{r}\text { Open } \\
(1\end{array}$ & water & & & & & & & & \\
\hline & 0.26 & 0.13 & & 0.00 & 0.00 & $\mathbf{0 . 0 0}$ & 0.00 & 0.00 & $\mathbf{0 . 0 0}$ & 0.00 & 0.00 & 0.00 & 0.00 & 0.00 & 0.00 & 0.00 & 0.00 & 0.00 & 0.00 \\
\hline $\begin{array}{l}\text { Brachyhyроротиs } \\
\text { beebei }\end{array}$ & 0.08 & 0.02 & & & & & & & & & & & & & & & & & \\
\hline Hypopomus artedi & 0.15 & 0.10 & & & & & & & & & & & & & & & & & \\
\hline Hyроротия sp. & - & & $\mathrm{x}$ & & & & & & & & & & & & & & & & \\
\hline Hypopygus lepturus & 0.03 & 0.01 & & & & & & & & & & & & & & & & & \\
\hline Rhamphichthyidae & 0.02 & 0.01 & & 0.00 & 0.00 & 0.00 & 0.00 & 0.00 & 0.00 & 0.00 & 0.00 & 0.00 & 0.00 & 0.00 & 0.00 & 0.00 & 0.00 & 0.00 & 0.00 \\
\hline $\begin{array}{l}\text { Gymnorhamphichthys } \\
\text { rondoni }\end{array}$ & 0.02 & 0.01 & & & & & & & & & & & & & & & & & \\
\hline Sternopygidae & 1.49 & 1.08 & & 0.00 & $\mathbf{0 . 0 0}$ & 1.63 & 1.01 & 0.54 & 0.55 & $\mathbf{0 . 0 0}$ & 0.00 & 0.22 & 0.41 & 0.00 & $\mathbf{0 . 0 0}$ & $\mathbf{0 . 0 0}$ & 0.00 & 0.08 & 0.03 \\
\hline $\begin{array}{l}\text { Eigenmannia aff. } \\
\text { virescens }\end{array}$ & 1.27 & 0.69 & & & & & & & & & & & & & & & & & \\
\hline Sternopygus macrurus & 0.22 & 0.39 & & & & 1.63 & 1.01 & 0.54 & 0.55 & & & 0.22 & 0.41 & & & & & 0.08 & 0.03 \\
\hline Siluriformes & 16.78 & 37.23 & & 6.31 & 0.56 & 8.09 & 10.85 & 6.34 & 5.95 & $\mathbf{0 . 0 0}$ & $\mathbf{0 . 0 0}$ & 0.99 & 1.83 & 0.00 & 0.00 & 0.00 & 0.00 & 0.36 & 0.15 \\
\hline Aspredinidae & 0.58 & 0.11 & & 0.00 & 0.00 & $\mathbf{0 . 0 0}$ & 0.00 & $\mathbf{0 . 0 0}$ & 0.00 & 0.00 & 0.00 & 0.00 & 0.00 & 0.00 & 0.00 & 0.00 & 0.00 & 0.00 & 0.00 \\
\hline Bunocephalus amaurus & 0.58 & 0.11 & & & & & & & & & & & & & & & & & \\
\hline Auchenipteridae & 1.18 & 0.31 & & 5.98 & 0.41 & 0.00 & 0.01 & 3.39 & 0.20 & 0.00 & $\mathbf{0 . 0 0}$ & 0.00 & 0.00 & 0.00 & 0.00 & 0.00 & 0.00 & 0.00 & 0.00 \\
\hline Auchenipterus nuchalis & 0.09 & 0.03 & & 5.98 & 0.41 & & 0.01 & 3.39 & 0.20 & & & & & & & & & & \\
\hline $\begin{array}{l}\text { Centromochlus } \\
\text { punctatus }\end{array}$ & 0.03 & 0.01 & & & & & & & & & & & & & & & & & \\
\hline $\begin{array}{l}\text { Pseudauchenipterus } \\
\text { nodosus }\end{array}$ & 0.02 & 0.00 & & & & & & & & & & & & & & & & & \\
\hline Tatia brunnea & 0.07 & 0.02 & & & & & & & & & & & & & & & & & \\
\hline $\begin{array}{l}\text { Trachelyopterus } \\
\text { galeatus }\end{array}$ & 0.96 & 0.25 & $\mathrm{x}$ & & & & & & & & & & & & & & & & \\
\hline Callichthyidae & 2.08 & 2.38 & & $\mathbf{0 . 0 0}$ & 0.00 & 0.00 & 0.00 & 0.00 & 0.00 & $\mathbf{0 . 0 0}$ & 0.00 & 0.00 & 0.00 & $\mathbf{0 . 0 0}$ & 0.00 & $\mathbf{0 . 0 0}$ & 0.00 & 0.00 & 0.00 \\
\hline Callichthys callichthys & 0.40 & 0.47 & $\mathrm{x}$ & & & & & & & & & & & & & & & & \\
\hline Corydoras aeneus & 0.09 & 0.01 & & & & & & & & & & & & & & & & & \\
\hline Corydoras boesemani & 0.12 & 0.01 & & & & & & & & & & & & & & & & & \\
\hline Corydoras geoffroy & 0.02 & 0.00 & & & & & & & & & & & & & & & & & \\
\hline Corydoras nanus & 0.04 & 0.00 & & & & & & & & & & & & & & & & & \\
\hline Corydoras punctatus & 0.93 & 0.10 & $\mathrm{x}$ & & & & & & & & & & & & & & & & \\
\hline Megalechis thoracata & 0.48 & 1.79 & $\mathrm{x}$ & & & & & & & & & & & & & & & & \\
\hline Cetopsidae & 0.10 & 0.01 & & 0.00 & 0.00 & $\mathbf{0 . 0 0}$ & 0.00 & 0.00 & 0.00 & 0.00 & 0.00 & 0.00 & 0.00 & 0.00 & 0.00 & 0.00 & 0.00 & 0.00 & 0.00 \\
\hline Helogenes marmoratus & 0.10 & 0.01 & & & & & & & & & & & & & & & & & \\
\hline Doradidae & 1.56 & 3.11 & & 0.00 & 0.00 & 0.79 & 1.81 & 0.26 & 1.12 & 0.00 & 0.00 & 0.04 & 0.20 & 0.00 & 0.00 & 0.00 & 0.00 & 0.02 & 0.02 \\
\hline Doras carinatus & 0.50 & 0.82 & & & & & & & & & & & & & & & & & \\
\hline Platydoras dentatus & 1.06 & 2.29 & & & & 0.79 & 1.81 & 0.26 & 1.12 & & & 0.04 & 0.20 & & & & & 0.02 & 0.02 \\
\hline Heptapteridae & 5.49 & 2.17 & & 0.00 & 0.00 & 0.00 & 0.00 & 0.00 & 0.00 & 0.00 & 0.00 & 0.04 & 0.03 & 0.00 & 0.00 & $\mathbf{0 . 0 0}$ & 0.00 & 0.02 & 0.00 \\
\hline Chasmocranus longior & 0.29 & 0.05 & & & & & & & & & & & & & & & & & \\
\hline $\begin{array}{l}\text { Chasmocranus } \\
\text { surinamensis* }\end{array}$ & 0.02 & 0.01 & & & & & & & & & & & & & & & & & \\
\hline Imparfinis cf. minutus & 0.02 & 0.01 & & & & & & & & & & & & & & & & & \\
\hline Imparfinis pijpersi & 0.15 & 0.02 & & & & & & & & & & & & & & & & & \\
\hline Pimelodella cristata & 4.70 & 1.94 & $\mathrm{x}$ & & & & & & & & & & & & & & & & \\
\hline Rhamdia quelen & 0.31 & 0.14 & $\mathrm{x}$ & & & & & & & & & 0.04 & 0.03 & & & & & 0.02 & 0.00 \\
\hline Loricariidae & 4.12 & 4.04 & & 0.33 & 0.15 & 7.30 & 9.02 & 2.68 & 5.62 & 0.00 & $\mathbf{0 . 0 0}$ & 0.91 & 1.60 & 0.00 & 0.00 & 0.00 & 0.00 & 0.32 & 0.13 \\
\hline $\begin{array}{l}\text { Ancistrus aff. } \\
\text { leucostictus }\end{array}$ & 0.03 & 0.03 & & & & & & & & & & & & & & & & & \\
\hline Ancistrus temminckii & 0.77 & 0.30 & & & & & & & & & & & & & & & & & \\
\hline $\begin{array}{l}\text { Cteniloricaria } \\
\text { maculata }\end{array}$ & 0.01 & 0.00 & & & & & & & & & & & & & & & & & \\
\hline Harttia surinamensis & 0.46 & 0.02 & & & & & & & & & & & & & & & & & \\
\hline $\begin{array}{l}\text { Hypostomus } \\
\text { gymnorhynchus }\end{array}$ & 0.03 & 0.02 & & & & & & & & & & & & & & & & & \\
\hline $\begin{array}{l}\text { Hypostomus } \\
\quad \text { micromaculatus* }\end{array}$ & 0.04 & 0.15 & & & & & & & & & & & & & & & & & \\
\hline $\begin{array}{l}\text { Hypostomus } \\
\text { paucimaculatus* }\end{array}$ & 0.02 & 0.01 & & & & & & & & & & & & & & & & & \\
\hline $\begin{array}{l}\text { Hypostomus } \\
\text { plecostomus }\end{array}$ & 0.02 & 0.03 & $\mathrm{x}$ & & & & & & & & & & & & & & & & \\
\hline $\begin{array}{l}\text { Hypostomus } \\
\text { surinamensis* }\end{array}$ & 0.30 & 1.72 & $\mathrm{x}$ & & & & & & & & & 0.13 & 0.29 & & & & & 0.05 & 0.02 \\
\hline $\begin{array}{l}\text { Hypostomus } \\
\text { ventromaculatus }\end{array}$ & 0.07 & 0.09 & $\mathrm{x}$ & 0.33 & 0.15 & 7.30 & 9.02 & 2.68 & 5.62 & & & & & & & & & & \\
\hline $\begin{array}{l}\text { Lithoxus } \\
\quad \text { pallidimaculatus* }\end{array}$ & 0.05 & 0.00 & & & & & & & & & & & & & & & & & \\
\hline Lithoxus surinamensis & 0.82 & 0.01 & & & & & & & & & & & & & & & & & \\
\hline Loricaria cataphracta & 0.29 & 0.23 & & & & & & & & & & & & & & & & & \\
\hline $\begin{array}{l}\text { Loricariichthys } \\
\quad \text { maculatus }\end{array}$ & 0.16 & 0.26 & $\mathrm{x}$ & & & & & & & & & 0.78 & 1.31 & & & & & 0.28 & 0.11 \\
\hline Metaloricaria nijsseni & 0.12 & 0.15 & & & & & & & & & & & & & & & & & \\
\hline $\begin{array}{l}\text { Pseudancistrus } \\
\text { barbatus }\end{array}$ & 0.37 & 1.54 & & & & & & & & & & & & & & & & & \\
\hline $\begin{array}{l}\text { Pseudancistrus } \\
\text { brevispinis }\end{array}$ & 0.40 & 0.48 & & & & & & & & & & & & & & & & & \\
\hline Rineloricaria stewarti & 0.18 & 0.02 & $\mathrm{x}$ & & & & & & & & & & & & & & & & \\
\hline
\end{tabular}


Appendix 1. Cont.

\begin{tabular}{|c|c|c|c|c|c|c|c|c|c|c|c|c|c|c|c|c|c|c|c|}
\hline \multirow[b]{4}{*}{ Pimelodidae } & \multirow{3}{*}{\multicolumn{2}{|c|}{$\begin{array}{c}\text { Suriname River } \\
\text { 1963-1964 } \\
(115)\end{array}$}} & \multicolumn{17}{|c|}{ Brokopondo Reservoir } \\
\hline & & & \multirow{3}{*}{$\begin{array}{l}1966 \\
1967 \\
\end{array}$} & \multicolumn{6}{|c|}{1978} & \multicolumn{10}{|c|}{$2002-2005$} \\
\hline & & & & \multicolumn{2}{|c|}{$\begin{array}{l}\text { Open water } \\
\text { (2) }\end{array}$} & \multicolumn{2}{|c|}{$\begin{array}{c}\text { Shore } \\
(3)^{1}\end{array}$} & \multicolumn{2}{|c|}{$\begin{array}{l}\text { Total } \\
(3 / 5)^{1}\end{array}$} & \multicolumn{2}{|c|}{$\begin{array}{l}\text { Open water } \\
\text { (17) }\end{array}$} & \multicolumn{2}{|c|}{$\begin{array}{l}\text { Shore } \\
(5)\end{array}$} & $\begin{array}{l}\mathrm{B} \\
(2\end{array}$ & $\begin{array}{l}\text { ay } \\
5)\end{array}$ & & 7) & & tal \\
\hline & 0.84 & 25.05 & & 0.00 & 0.00 & 0.00 & 0.01 & 0.00 & 0.01 & 0.00 & 0.00 & 0.00 & 0.00 & 0.00 & 0.00 & 0.00 & 0.00 & 0.00 & $\mathbf{0 . 0 0}$ \\
\hline $\begin{array}{l}\text { Brachyplatystoma } \\
\text { filamentosum }^{3}\end{array}$ & 0.01 & 17.01 & & & & & & & & & & & & & & & & & \\
\hline $\begin{array}{l}\text { Hemisorubim } \\
\text { platyrhynchos }\end{array}$ & 0.03 & 0.14 & $\mathrm{x}$ & & & & & & & & & & & & & & & & \\
\hline Pimelodus blochii & 0.30 & 0.46 & & & & & $0.01^{4}$ & & 0.01 & & & & & & & & & & \\
\hline Pimelodus ornatus & 0.49 & 2.90 & & & & & & & & & & & & & & & & & \\
\hline $\begin{array}{l}\text { Pseudoplatystoma } \\
\text { fasciatum }\end{array}$ & 0.01 & 4.54 & $\mathrm{x}$ & & & & & & & & & & & & & & & & \\
\hline Pseudopimelodidae & 0.63 & 0.04 & & 0.00 & 0.00 & 0.00 & 0.00 & 0.00 & 0.00 & 0.00 & 0.00 & 0.00 & 0.00 & $\mathbf{0 . 0 0}$ & 0.00 & 0.00 & 0.00 & 0.00 & 0.00 \\
\hline Batrochoglanis raninus & 0.02 & 0.01 & $\mathrm{x}$ & & & & & & & & & & & & & & & & \\
\hline Microglanis poecilus & 0.56 & 0.01 & $\mathrm{x}$ & & & & & & & & & & & & & & & & \\
\hline Microglanis secundus & 0.03 & 0.00 & & & & & & & & & & & & & & & & & \\
\hline $\begin{array}{l}\text { Pseudopimelodus } \\
\text { bufonius }\end{array}$ & 0.02 & 0.02 & & & & & & & & & & & & & & & & & \\
\hline $\begin{array}{l}\text { Trichomycteridae } \\
\text { Ituglanis amazonicus }\end{array}$ & $\begin{array}{l}\mathbf{0 . 2 0} \\
0.06\end{array}$ & $\begin{array}{l}\mathbf{0 . 0 1} \\
0.00\end{array}$ & & 0.00 & 0.00 & 0.00 & 0.00 & 0.00 & 0.00 & 0.00 & 0.00 & 0.00 & 0.00 & 0.00 & 0.00 & 0.00 & 0.00 & 0.00 & 0.00 \\
\hline $\begin{array}{l}\text { Ochmacanthus aff. } \\
\text { flabelliferus }\end{array}$ & 0.14 & 0.01 & & & & & & & & & & & & & & & & & \\
\hline Perciformes & 21.45 & 12.97 & & 0.99 & 0.51 & 38.07 & 51.81 & 13.32 & 29.97 & 0.40 & 1.78 & 56.68 & 56.00 & 0.89 & 5.47 & 14.00 & 17.81 & 21.94 & 8.27 \\
\hline Cichlidae & 21.05 & 12.78 & & 0.99 & 0.51 & 38.07 & 51.81 & 13.32 & 29.97 & 0.40 & 1.78 & 56.68 & 56.00 . & 0.59 & 2.93 & 14.00 & 17.81 & 21.85 & 7.13 \\
\hline Aequidens tetramerus & 0.02 & 0.03 & $\mathrm{x}$ & & & & & & & & & & & & & & & & \\
\hline $\begin{array}{l}\text { Apistogramma } \\
\text { steindachneri }\end{array}$ & 0.83 & 0.04 & $\mathrm{x}$ & & & & & & & & & & & & & & & & \\
\hline Cichla ocellaris & 1.52 & 1.60 & $\mathrm{x}$ & 0.33 & 0.01 & 7.70 & 34.00 & 2.73 & 18.16 & 0.40 & 1.78 & 6.54 & 5.90 & 0.54 & 2.92 & 6.13 & 8.27 & 3.20 & 2.77 \\
\hline $\begin{array}{l}\text { Cichlasoma } \\
\text { bimaculatum }\end{array}$ & 3.49 & 0.79 & $\mathrm{x}$ & & & 0.65 & 2.50 & 0.22 & 2.00 & & & 2.47 & 2.52 & & & & & 0.88 & 0.21 \\
\hline $\begin{array}{l}\text { Crenicichla } \\
\text { multispinosa }\end{array}$ & 0.11 & 0.21 & & & & & $0.50^{5}$ & & 0.30 & & & 0.78 & 1.03 & & & 0.16 & 0.18 & 0.29 & 0.09 \\
\hline Crenicichla saxatilis & 2.20 & 2.11 & $\mathrm{x}$ & & & & 0.63 & & 0.30 & & & 2.43 & 2.55 & & & & & 0.86 & 0.21 \\
\hline $\begin{array}{l}\text { Geophagus } \\
\text { surinamensis }\end{array}$ & 5.65 & 4.93 & $\mathrm{x}$ & 0.66 & 0.50 & 28.37 & 9.02 & 9.92 & 4.97 & & & 17.85 & 31.46 & 0.05 & 0.01 & 7.55 & 9.34 & 7.12 & 2.81 \\
\hline Guianacara owroewefi & 4.14 & 1.71 & $x^{6}$ & & & 0.65 & 2.50 & 0.22 & 2.10 & & & 23.27 & 6.30 & & & 0.16 & 0.02 & 8.31 & 0.52 \\
\hline Krobia guianensis & 2.60 & 1.35 & $\mathrm{x}$ & & & 0.70 & 2.66 & 0.23 & 2.14 & & & 3.34 & 6.24 & & & & & 1.19 & 0.52 \\
\hline Nannacara anomala & 0.51 & 0.02 & $\mathrm{x}$ & & & & & & & & & & & & & & & & \\
\hline Nandidae & 0.31 & 0.01 & & 0.00 & 0.00 & 0.00 & 0.00 & 0.00 & 0.00 & 0.00 & 0.00 & 0.00 & 0.00 & 0.00 & 0.00 & 0.00 & 0.00 & 0.00 & 0.00 \\
\hline $\begin{array}{l}\text { Polycentrus } \\
\text { schomburgkii }\end{array}$ & 0.31 & 0.01 & $\mathrm{x}$ & & & & & & & & & & & & & & & & \\
\hline Sciaenidae & 0.09 & $\mathbf{0 . 1 8}$ & & 0.00 & 0.00 & $\mathbf{0 . 0 0}$ & 0.00 & 0.00 & 0.00 & 0.00 & 0.00 & $\mathbf{0 . 0 0}$ & 0.00 & 0.30 & 2.54 & $\mathbf{0 . 0 0}$ & $\mathbf{0 . 0 0}$ & 0.09 & 1.14 \\
\hline $\begin{array}{l}\text { Pachypops fourcroi } \\
\text { Plagioscion auratus }\end{array}$ & $\begin{array}{l}0.04 \\
0.04\end{array}$ & $\begin{array}{l}0.07 \\
0.08\end{array}$ & & & & & & & & & & & & & & & & $x^{2}$ & \\
\hline $\begin{array}{l}\text { Plagioscion } \\
\text { squamosissimus }\end{array}$ & $x^{2}$ & & & & & & & & & & & & & 0.30 & 2.54 & & & 0.09 & 1.14 \\
\hline $\begin{array}{l}\text { Plagioscion } \\
\text { surinamensis }\end{array}$ & 0.02 & 0.04 & & & & & & & & & & & & & & & & $\mathrm{x}^{2}$ & \\
\hline Miscellaneous groups & 1.32 & 2.33 & & 0.00 & 0.00 & 0.00 & 0.03 & 0.00 & 0.02 & 0.00 & 0.00 & 0.04 & 4.87 & 0.00 & 0.00 & 0.16 & 19.05 & 0.03 & 0.81 \\
\hline Achiridae & 0.02 & 0.01 & & 0.00 & 0.00 & 0.00 & 0.00 & 0.00 & 0.00 & 0.00 & 0.00 & 0.00 & 0.00 & 0.00 & 0.00 & 0.00 & 0.00 & 0.00 & 0.00 \\
\hline Apionichthys dumerili & 0.02 & 0.01 & & & & & & & & & & & & & & & & & \\
\hline Belonidae & 0.63 & 0.35 & & 0.00 & 0.00 & 0.00 & 0.00 & 0.00 & 0.00 & 0.00 & 0.00 & 0.00 & 0.00 & 0.00 & 0.00 & $\mathbf{0 . 0 0}$ & 0.00 & 0.00 & 0.00 \\
\hline $\begin{array}{l}\text { Potamorrhaphis } \\
\text { guianensis }\end{array}$ & 0.63 & 0.35 & & & & & & & & & & & & & & & & & \\
\hline Rivulidae & 0.16 & 0.01 & & 0.00 & 0.00 & $\mathbf{0 . 0 0}$ & 0.00 & 0.00 & 0.00 & 0.00 & 0.00 & 0.00 & 0.00 & 0.00 & 0.00 & 0.00 & 0.00 & 0.00 & $\mathbf{0 . 0 0}$ \\
\hline Rivulus agilae & 0.01 & 0.00 & & & & & & & & & & & & & & & & & \\
\hline Rivulus aff. holmiae & 0.09 & 0.01 & & & & & & & & & & & & & & & & & \\
\hline $\begin{array}{l}\text { Rivulus aff. } \\
\text { urophthalmus }\end{array}$ & 0.04 & 0.00 & & & & & & & & & & & & & & & & & \\
\hline Rivulus spp. & 0.02 & 0.00 & & & & & & & & & & & & & & & & & \\
\hline $\begin{array}{l}\text { Engraulididae } \\
\text { Anchovia surinamensis }\end{array}$ & $\begin{array}{l}\mathbf{0 . 3 0} \\
0.25\end{array}$ & $\begin{array}{l}\mathbf{0 . 1 1} \\
0.04\end{array}$ & & 0.00 & 0.00 & 0.00 & 0.00 & 0.00 & $\mathbf{0 . 0 0}$ & 0.00 & 0.00 & 0.00 & 0.00 & 0.00 & 0.00 & $\mathbf{0 . 0 0}$ & $\mathbf{0 . 0 0}$ & 0.00 & 0.00 \\
\hline $\begin{array}{l}\text { Anchoviella } \\
\quad \text { lepidentostole }\end{array}$ & 0.02 & 0.01 & & & & & & & & & & & & & & & & & \\
\hline Lycengraulis batesii & 0.03 & 0.06 & & & & & & & & & & & & & & & & & \\
\hline $\begin{array}{l}\text { Megalopidae } \\
\text { Megalops atlanticus }\end{array}$ & $\mathrm{x}^{7}$ & & & 0.00 & 0.00 & 0.00 & 0.00 & 0.00 & $\mathbf{0 . 0 0}$ & 0.00 & 0.00 & 0.00 & $\mathbf{0 . 0 0}$ & $\mathbf{0 . 0 0}$ & 0.00 & $\mathbf{0 . 0 0}$ & 0.00 & 0.00 & 0.00 \\
\hline $\begin{array}{l}\text { Poeciliidae } \\
\text { Micropoecilia bifurca }\end{array}$ & $x^{8}$ & & $x^{8}$ & 0.00 & 0.00 & 0.00 & 0.00 & 0.00 & 0.00 & 0.00 & 0.00 & 0.00 & 0.00 & 0.00 & 0.00 & 0.00 & 0.00 & 0.00 & 0.00 \\
\hline Potamotrygonidae & 0.12 & 1.78 & & 0.00 & 0.00 & 0.00 & 0.03 & 0.00 & 0.00 & 0.00 & 0.00 & 0.04 & 4.87 & 0.00 & 0.00 & 0.16 & 19.05 & 0.00 & 0.81 \\
\hline Potamotrygon orbignyi & 0.12 & 1.78 & & & & & & & & & & 0.04 & 4.87 & & & 0.16 & 19.05 & 0.03 & 0.81 \\
\hline Synbranchidae & 0.10 & 0.06 & & $\mathbf{0 . 0 0}$ & 0.00 & 0.00 & 0.00 & 0.00 & 0.00 & 0.00 & 0.00 & 0.00 & 0.00 & 0.00 & 0.00 & $\mathbf{0 . 0 0}$ & 0.00 & 0.00 & 0.00 \\
\hline $\begin{array}{l}\text { Synbranchus } \\
\text { marmoratus } \\
\end{array}$ & 0.10 & 0.06 & $\mathrm{x}$ & & & & 0.03 & & 0.02 & & & & & & & & & & \\
\hline $\begin{array}{l}\text { total number of } \\
\text { specimens / biomass } \\
(\mathrm{kg})\end{array}$ & 12842 & 176.4 & & 301 & 67.9 & 2540 & $26.0^{9}$ & 2841 & - & 1511 & 110.9 & 2308 & 20.5 & 2020 & 110.5 & 636 & 5.2 & 6475 & 247.1 \\
\hline total number of species & 172 & & 62 & 11 & & 31 & & 35 & & 10 & & 27 & & 23 & & 11 & & 41 & \\
\hline Species diversity $H$ & 4.11 & 3.76 & & 1.49 & 0.46 & 1.48 & 2.26 & 1.82 & 2.04 & 0.88 & 0.62 & 2.29 & 2.43 & 1.58 & 1.51 & 1.31 & 1.81 & 2.17 & 1.53 \\
\hline Evenness $J$ & 0.80 & 0.74 & & 0.62 & 0.19 & 0.60 & 0.65 & 0.75 & 0.61 & 0.38 & 0.27 & 0.70 & 0.74 & 0.51 & 0.48 & 0.54 & 0.75 & 0.60 & 0.42 \\
\hline
\end{tabular}

